\title{
Febre catarral maligna em bovinos no Rio Grande do Sul: transmissão experimental para bovinos e caracterização do agente etiológico ${ }^{1}$
}

\author{
Shana L. Garmatz ${ }^{2}$, Luiz F. Irigoyen ${ }^{3}$, Raquel R. Rech², Corrie C. Brown ${ }^{4}$, Jian \\ Zhang $^{4}$ e Claudio S. L. Barros ${ }^{3 *}$
}

\begin{abstract}
Garmatz S.L., Irigoyen L.F., Rech R.R., Brown C.C., Zhang]. \& Barros C.S.L. 2004. [Malignant catarrhal fever in cattle in Rio Grande do Sul, Brazil: Experimental transmission to cattle and characterization of the etiological agent.] Febre catarral maligna em bovinos no Rio Grande do Sul: transmissão experimental para bovinos e caracterização do agente etiológico. Pesquisa Veterinária Brasileira 24(2):93-106. Depto Patologia, Universidade Federal de Santa Maria, 97105-900 Santa Maria, RS, Brazil. E-mail: claudioslbarros@ uol.com.br

Two oubreaks of malignant catarrhal fever (MCF) occurring in cattle on two farms ( $A$ and $B$ ) in the municipality of Santiago, state of Rio Grande do Sul (RS), Brazil, and the transmission of the disease to susceptible calves as well as the detection of ovine herpesvirus-2 (OvHV-2) in tissues of affected cattle are reported. The two epizootics occurred from November 2001 to February 2002 (Farm A) and in January-February 2003 (Farm B). Numbers of cattleat risk, morbidity and letality rates were respectively 170, 10.59\%and 83.33\%for Farm A and 500, 2.4\%and 100\%for Farm B. Contact between affected cattle and sheep was detected in both farms, but lambing ewes were present only in farm A. Duration of clinical courses, gross findings and histopathology were the same for the affected cattle in both farms. Most affected cattle died or were euthanatized in extremis after a clinical course of 2-8 days. Clinical signs included fever $\left(40.5\right.$ and $\left.41.5^{\circ} \mathrm{C}\right)$, nasal and ocular discharge, corneal opacity, conjunctivitis, drooling, erosions and ulcerations of the mucosae, diarrhea, hematuria, and neurological disturbances. Eleven necropsies (9 on Farm A, 2 on Farm B) were performed. Gross lesions included erosions and ulcers affecting the mucosae of nasal turbinates, oral cavity, gastrointestinal and urogenital tracts; hemorrhage and necrosis of the tip of the buccal papillae, lymph node enlargement, multifocal white foci in renal cortex, and hyperemia of leptomeninges. Microscopically, there were arteritis and fibrinoid degeneration in medium and small arteries and arterioles of multiple organs and tissues, necrosis and inflammation in several mucosal surfaces, keratitis, conjunctivitis, uveitis, intersticial nephritis, and encephalitis. Transmission experiments were attempted in five calves (E1-E5) by inocculating each of them intravenously with $500 \mathrm{ml}$ of whole heparinized blood from a MCF affected cow. The transmission was suscessful in at least three (E1-E3) of the experimental calves which became sick after an incubation period of 15-27 days. Four experimental calves either died or were euthanatized in extremis after a clinical course which varied from 3 days to 8 weeks. The remaining experimental calf (E5) recovered from a mild disease and was euthanatized 14 weeks after inocculation. Necropsies were performed in all five calves. Clinical signs, necropsy and histopathological findings of three calves (E1-E3) were characteristic of MCF. OvHV-2 viral DNA was detected by the polimerase chain reaction (PCR) test in paraffin embedded tissues from seven cattle out of the 11 spontaneous
\end{abstract}

${ }^{1}$ Recebido em 18 de março de 2004.

Aceito para publicação em 12 de abril de 2004.

Realizado com apoio financeiro do Programa de Apoio a Núcleos de Excelência (PRONEX), Proc. CNPq 7697102600. Parte da Dissertação de Mestrado do primeiro autor.

2 Programa de Pós-Graduação em Medicina Veterinária, área de concen- tração em Patologia Veterinária, Centro de Ciências Rurais, Universidade Federal de Santa Maria (UFSM).

${ }^{3}$ Departamento de Patologia, UFSM, 97105-900 Santa Maria, Rio Grande do Sul. *Autor para correspondência. E-mail: claudioslbarros@uol.com.br

${ }^{4}$ Department of Veterinary Pathology, College of Veterinary Medicine, University of Georgia, Athens, GA 30602-7388, Estados Unidos. 
MCF cases and from three experimental calves (E1-E3). PCR tests resulted negative in the remaining four of the 11 spontaneous MCF cases tested and in two $(E 4, E 5)$ of the five experimental calves. Immunohistochemistry performed in sections of lymphoid tissue from calf E4 failed to detect BVD virus antigen. The experimental transmission of MCF and the characterization of the etiological agent as OvHV-2 were successfully attempted in cattle for the first time in Brazil.

INDEX TERMS: Infectious diseases, malignant catarrhal fever, viral diseases, diseases of cattle, pathology, polimerase chain reation.

RESUMO.- São relatados dois surtos de febre catarral maligna (FCM) em bovinos de duas propriedades rurais (A e B) do município de Santiago, Rio Grande do Sul (RS), a transmissão da doença a bovinos suscetíveis e a detecção de DNA viral de herpesvírus bovino-2 (OvHV-2) em tecidos de bovinos afetados. Os dois surtos ocorreram de novembro de 2001 a fevereiro de 2002 (Propriedade A) e de janeiro a fevereiro de 2003 (Propriedade B). 0 número de bovinos sob risco, as taxas de morbidadee de letalidade foram, respectivamente, $170,10,59 \%$ e $83,33 \%$ na Propriedade A e 500, $2,4 \%$ e $100 \%$ na Propriedade B. Em ambas as propriedades havia contato de ovinos com os bovinos afetados, mas somente na Propriedade A havia ovelhas em parição. Nos bovinos afetados nas duas propriedades, a duração do curso clínico, os achados de necropsia e a histopatologia foram semelhantes. A maioria dos bovinos afetados morreu ou foi submetida à eutanásia in extremis após um curso clínico de 2 a 8 dias. Os sinais clínicos incluíam febre $\left(40,5\right.$ e $\left.41,5^{\circ} \mathrm{C}\right)$, corrimento nasal e ocular, opacidade da córnea, conjuntivite, salivação, erosões e ulcerações em mucosas, diarréia, hematúria e distúrbios neurológicos. Foram realizadas onze necropsias (nove na Propriedade A e duas na Propriedade B). Lesões macroscópicas incluíam erosões e úlceras nas mucosas dos cornetos nasais, cavidade oral e tratos gastrintestinal e urogenital; hemorragia e necrose da ponta das papilas bucais, aumento de volume dos linfonodos, múltiplos focos brancos no córtex renal e hiperemia das leptomeninges. Microscopicamente, havia arterite e degeneração fibrinóide em artérias de médio e pequeno calibre e em arteríolas de múltiplos órgãos e tecidos, necrose e inflamação em várias superfícies mucosas, ceratite, conjuntivite, uveíte, nefrite intersticial e encefalite. A transmissão experimental foi tentada em cinco bezerros (E1-E5) através da inoculação de cada um deles, por via intravenosa, com $500 \mathrm{ml}$ de sangue total heparinizado oriundo de bovino afetado por FCM. A transmissão foi conseguida em pelo menos três (E1-E3) dos bezerros experimentais que adoeceram após um período de incubação de 15 a 27 dias. Quatro dos bezerros do experimento morreram ou foram submetidos à eutanásia in extremis após um curso clínico que durou de 3 dias a 8 semanas. 0 bezerro experimental remanescente (E5) recuperou-se após uma doença branda e foi submetido à eutanásia 14 semanas após a inoculação. Os cinco bezerros foram necropsiados. Sinais clínicos, achados de necropsia e histopatologia de três bezerros (E1-E3) eram característicos de FCM. O DNA viral de OvHV-2 foi detectado pela técnica de reação em cadeia de polimerase (PCR) em tecidos emblocados em parafina de sete dos 11 bovinos espontaneamente afetados por FCM e em tecidos emblocados em parafina de três bezerros experimentais (E1-E3). A técnica de PCR resultou negativa nos restantes quatro dos 11 bovinos testados nos casos espontâneos de FCM e em dois (E4-E5) dos cinco bezerros usados nos experimentos de trans- missão. Testes de imunoistoquímica realizados em cortes de tecido linfóide do bezerro E4 resultaram negativos para antígeno do vírus da diarréia viral bovina. A transmissão experimental de FCM de bovino para bovino e a caracterização do agente etiológico da doença em bovinos como OvHV-2 foi conseguida pela primeira vez no Brasil.

TERMOS DE INDEXAÇÃO: Doenças infecciosas, febre catarral maligna, doenças a vírus, doenças de bovinos, patologia, reação em cadeia de polimerase.

\section{INTRODUÇÃO}

A febre catarral maligna (FCM) é uma doença infecciosa, viral, pansistêmica, altamente fatal, com distribuição geográfica ampla. Além de bovinos, afeta mais de 30 espécies de ruminantes (Plowright 1990), incluindo diversas espécies de cervídeos (Driemeier et al. 2002) e, ocasionalmente, suínos (Løken et al. 1998). Caracteriza-se por febre alta, depressão, corrimento nasal e ocular, erosões e ulcerações na mucosa do trato respiratório superior, ceratoconjuntivite, linfadenopatia, enterite hemorrágica, diarréia, encefalite, exantema cutâneo e artrite (Selman et al. 1974, Barker et al. 1993, Barnard et al. 1994). As lesões macro e microscópicas envolvem principalmente os tratos digestivo, respiratório superior e urinário, linfonodos, fígado, olhos e encéfalo. As lesões histológicas características consistem vasculite, infiltrados mononucleares em vários órgãos, hiperplasia linfóide e necrose dos epitélios de revestimento (Barker et al. 1993).

0 "grupo de vírus da FCM" pertence ao gênero Rhadinovirus da família Gammaherpesvirinae (Coulter et al. 2001). A maioria das espécies de ruminantes, domésticos ou selvagens, possui seu radinovírus específico eébem adaptada a ele, i.é, esses vírus induzem pouco ou nenhum efeito em seus hospedeiros naturais, mas podem causar doença quando afetam espécies diferentes pouco adaptadas (Crawford et al. 2002). Até o momento, foram identificados quatro vírus do grupo da FCM que causam doença em animais (Li et al. 2003a). A forma africana, ou FCM gnu-associada (FCM-GA), éinduzida pela cepa alcelaphine herpesvírus 1 (AlHV-1) (Coulter et al. 2001). AlHV-1 étransmitido por gnus (Connochaetes taurinus e C. gnu, subfamília Alcelaphine). Em locais onde não há gnus ocorre a forma denominada FCM não associada a gnus ou FCM ovino-associada (FCM-OA), pois ovinos são implicados como portadores do agente etiológico, denominado herpesvírus ovino2 (OvHV-2) (Roizman et al. 1981, Bridgen \& Reid 1991). As manifestações clínicas e patológicas das formas induzidas por AlHV-1 e OvHV-2 são as mesmas, mas há diferenças epidemiológicas entre as duas (Smith 2002). Um terceiro vírus desse grupo (Li et al. 2000) induz a FCM clássica no veado-de-cauda-branca (Odocoileus 
virginianus); além desses, um vírus endêmico em cabras domésticas, provisoriamente denominado herpesvírus caprino-2 ou CpHV2 (Chmielewicz et al. 2001, Li et al. 2001b), tem sido associado com alopecia, dermatite, perda de peso crônica e diarréia em veadossika (Cervusnippon) e veados-de-cauda-branca (Crawford et al. 2002, Keel et al. 2003, Li et al. 2003b).

Ao contrário de A1HV-1, que já foi isolado em cultura, os outros três agentes patogênicos da FCM são detectados apenas por técnicas moleculares como a reação em cadeia de polimerase - PCR (Crawford et al. 1999). Atualmente, a técnica da PCR tem sido usada para o diagnóstico da FCM-OA (O'Toole et al.1995, Simon et al. 2003). Suas vantagens sobre o exame histopatológico incluem: (a) a técnica poder ser feita in vitro, (b) tem grande sensibilidade e especificidade (Müller-Doblies et al. 1998), (c) permite diagnosticar casos de FCM que não apresentem todos os sinais clínicos clássicos, como os casos crônicos com recuperação da doença clínica (O'Toole et al.1995, 1997) e (d) a aplicação da técnica em tecidos fixados e emblocados em parafina pode ser utilizada para caracterizar 0 agente, especialmente para estudos retrospectivos (Tham 1997, Crawford et al. 1999). Limitações da técnica quando aplicadas a materiais fixados e emblocados em parafina estão relacionadas à desnaturação do ácido nucléico por fixação muito prolongada ou em formol nãotamponado (Crawford et al. 1999).

A FCM em bovinos no Brasil tem sido relatada em casos diagnosticados pelos sinais clínicos, achados de necropsia e histopatologia (Torres 1924, Döbereiner \& Tokarnia 1959, Sampaio et al. 1972, Oliveira et al. 1978; Figueiredo et al. 1990, Barros et al. 1983, Marques et al. 1986, Riet-Correa et al. 1988, Baptista \& Guidi 1998, Silva et al. 2001). Testes para transmissão da doença e caracterização do agente etiológico não têm sido real izados ou têm sido realizados sem sucesso (Döbereiner \& Tokarnia 1959). Sendo assim, não há documentação do tipo de vírus que causa a doença em bovinos no país. Os sinais clínicos e as lesões macroscópicas na FCM são geralmente característicos, mas podem ser variados e inespecíficos, especialmente nos casos leves, hiperagudos ou crônicos. Nesses casos, o diagnóstico deve ser baseado na detecção de alterações histológicas características e resultados positivos de experimentos de transmissão e técnicas laboratoriais para determinar a etiologia.

Nos anos de 2001 a 2003, dois surtos importantes de FCM ocorreram em bovinos de duas propriedades do município de Santiago, Rio Grande do Sul. 0 objetivo deste trabalho foi estudar esses dois surtos considerando os seguintes aspectos: (a) levantamento de dados epidemiológicos, (b) determinação do quadro clínico e patológico da doença, (c) comprovação da natureza da doença através da transmissão a bovinos susceptíveis e (d) determinação da natureza do agente etiológico através da técnica de PCR.

\section{MATERIAL E MÉTODOS}

\section{Casos espontâneos}

Os dados epidemiológicos e clínicos foram colhidos através de visitas às fazendas onde estavam ocorrendo os surtos, designadas Propriedades A e B. Cinco visitas foram realizadas na Propriedade A e uma visita na Propriedade B. Os dados foram complementados por questionários aplicados ao proprietário, ao administrador e a outros trabalhadores da fazenda. Nove bovinos (identificados pelos números 1-9) e dois bovinos (identificados como 10 e 11) foram necropsiados nas Propriedades A e B, respectivamente. Nove bovinos (1-8 e 11) foram necropsiados por docentes e pós-graduandos do Laboratório de Patologia (LP) do Departamento de Patologia, Universidade Federal de Santa Maria, e dois bovinos (9 e 10) foram necropsiados por veterinários de campo e o material foi enviado ao LP para exame macroscópico e histológico. Os dados de necropsia apresentados referem-se aos Bovinos 1-8 e 11. Fragmentos de diversos tecidos dos bovinos necropsiados foram coletados e fixados em formol a $10 \%$ e processados para exame histológico.

\section{Transmissão experimental}

Os dados dos cinco bezerros utilizados no experimento encontramse no Quadro 1. Três desses bezerros (E1-E3), foram adquiridos do Setor de Zootecnia da Universidade Federal de Santa Maria e os outros dois (E4-E5) vieram da Propriedade A, em Santiago, Rio Grande do Sul, onde havia ocorrido um dos surtos espontâneos de FCM em 2001-2002. Os bezerros estavam em estado nutricional 3, com exceção do Bovino E1 que apresentava estado nutricional 1, segundo a mesma classificação de estado corporal (Stöber et al. 1990). Durante o experimento, os bezerros foram mantidos em baias de alvenaria com piso recoberto por serragem e recebiam feno de alfafa e água à vontade. Um exame consistindo de inspeção visual e aferição da temperatura corporal era realizado diariamente nos bezerros.

Em todos os casos, o inóculo consistiu de $500 \mathrm{ml}$ de sangue retirado de um bovino com diagnóstico de FCM e com sinais avançados da

Quadro 1. Dados dos bovinos experimentais inoculados com $500 \mathrm{ml}$ de sangue total heparinizado colhido de bovino clinicamente afetado por febre catarral maligna

\begin{tabular}{cccccc}
\hline Bovino & $\begin{array}{c}\text { Idade } \\
\text { (meses) }\end{array}$ & Sexo & Raça & $\begin{array}{c}\text { Origem do san- } \\
\text { gue inoculado }\end{array}$ & $\begin{array}{c}\text { Data de } \\
\text { inoculação }\end{array}$ \\
\hline E1 & 8 & M $^{\text {a }}$ & Charolês x Nelore & Bovino 5 & 21.12 .01 \\
E2 & 6 & M & Nelore & Bovino E1 & 18.12 .01 \\
E3 & 5 & F & Tabapuã x Charolês & Bovino E1 & 18.12 .01 \\
E4 & 12 & F & Charolês & Bovino E2 & 05.02 .02 \\
E5 & 8 & F & Tabapuã & Bovino E2 & 05.02 .02
\end{tabular}

aMacho, bfêmea.

doença. 0 primeiro inóculo foi obtido do Bovino 5, uma fêmea de 3 anos, na fase terminal da doença. 0 diagnóstico de FCM foi posteriormente confirmado pela necropsia e histopatologia no Bovino 5. O sangue total desse bovino foi inoculado no Bovino E1 (primeira passagem). Quando o Bovino E1 adoeceu, seu sangue foi inoculado nos Bovinos E2 e E3 (segunda passagem). Quando o Bovino E2 adoeceu, seu sangue foi inoculado nos Bovinos E4 e E5 (terceira passagem).

Cada um dos cinco bezerros do experimento recebeu $500 \mathrm{ml}$ do sangue total de animal afetado por FCM. A inoculação foi baseada em um método alternativo desenvolvido para coleta e transfusão de sangue. Detalhes dessa técnica podem ser encontrados em publicação especializada (Raiser et al. 2003). Resumidamente, 500 ou $1.000 \mathrm{ml}$ de sangue foram colhidos da jugular de cada bovino doador do sangue a ser inoculado em garrafas plásticas de 1,5 litro de capacidade contendo heparina ${ }^{5}$ ( $5 \mathrm{UI}$ por $\mathrm{ml}$ de sangue colhido). Durante a coleta, o vácuo era produzido com seringa plástica de $60 \mathrm{ml}$, torneira de três vias e equipos de coleta e transfusão de sangue. Em seguida $500 \mathrm{ml}$

\footnotetext{
${ }^{5}$ Heparina: Cristália Produtos Químicos Farmacêuticos Ltda.
} 
desse sangue foi transfundido na jugular de cada um dos cinco bovinos do experimento. Para a transfusão do sangue, em cada receptor foi utilizado equipo de transfusão com filtros contendo poros de $170 \mu \mathrm{m}$.

Após a morte espontânea (Bov. E2-E4) ou eutanásia (Bov. E1 e E5), os bovinos do experimento foram necropsiados. 0 material de diversosórgãos foi processado parahistopatologia de maneira idêntica à dos casosnaturais. Fragmentos detonsila do Bovino E4 incluídosem parafina foram seccionados e submetidos ao método imunoistoquímico de estreptavidina-biotina peroxidase para o vírus da diarréia viral bovina (BVD) utilizando o anticorpo monoclonal anti BVD 15C5 na diluição de 1:500.

\section{Reação em cadeia de polimerase (PCR)}

A identificação dos bovinos e a relação dos tecidos submetidos à técnica de PCR encontram-se no Quadro 2. Como controles positivos foram utilizados intestino e linfonodo emblocados em parafina provenientes de um bisão positivo para OvHV-2 (Simon et al. 2003)

Quadro 2. Relação dos tecidos examinados pela técnica de reação da polimerase em cadeia (PCR). Onze bovinos (1 a

11) são casos espontâneos de febre catarral maligna. Cinco bovinos (E1-E5) foram usados nos experimentos de transmissão

\begin{tabular}{|c|c|c|c|c|c|c|c|c|c|c|c|c|c|c|c|c|}
\hline \multirow[t]{2}{*}{ Órgão } & \multicolumn{16}{|c|}{ Bovino } \\
\hline & 1 & 2 & 3 & 4 & 5 & 6 & 7 & 8 & 9 & 10 & 11 & E1 & E2 & E3 & E4 & E5 \\
\hline Abomaso & $0^{a}$ & 0 & 0 & 0 & 0 & 0 & 0 & - $b$ & 0 & 0 & 0 & 0 & 0 & 0 & 0 & 0 \\
\hline Adrenal & 0 & 0 & 0 & 0 & 0 & 0 & 0 & • & 0 & 0 & - & 0 & 0 & 0 & 0 & 0 \\
\hline Baço & 0 & 0 & 0 & 0 & • & 0 & • & 0 & 0 & - & 0 & 0 & 0 & 0 & - & • \\
\hline Bexiga & 0 & 0 & 0 & 0 & 0 & 0 & - & • & - & 0 & • & 0 & 0 & • & 0 & 0 \\
\hline Bochecha & 0 & 0 & 0 & 0 & 0 & 0 & 0 & • & 0 & 0 & 0 & 0 & 0 & 0 & 0 & 0 \\
\hline Cornetos & 0 & 0 & 0 & $\bullet$ & 0 & 0 & 0 & 0 & 0 & 0 & 0 & - & - & • & 0 & 0 \\
\hline Encéfalo & 0 & • & • & 0 & $\bullet$ & 0 & 0 & 0 & - & • & 0 & - & 0 & - & 0 & 0 \\
\hline Fígado & • & 0 & 0 & 0 & 0 & 0 & 0 & $\bullet$ & - & • & $\bullet$ & - & 0 & - & - & • \\
\hline Focinho & 0 & 0 & 0 & 0 & 0 & 0 & 0 & 0 & - & 0 & $\bullet$ & 0 & 0 & 0 & 0 & 0 \\
\hline Int. delgado ${ }^{C}$ & 0 & 0 & 0 & $\bullet$ & 0 & - & 0 & 0 & 0 & 0 & $\bullet$ & 0 & 0 & - & 0 & 0 \\
\hline Int. grossod & 0 & 0 & 0 & 0 & • & 0 & 0 & 0 & 0 & 0 & 0 & 0 & 0 & 0 & 0 & 0 \\
\hline Língua & 0 & 0 & 0 & 0 & 0 & 0 & 0 & 0 & 0 & 0 & 0 & 0 & 0 & 0 & - & 0 \\
\hline Linfonodo & 0 & 0 & • & 0 & - & - & 0 & $\bullet$ & 0 & 0 & $\bullet$ & 0 & 0 & 0 & 0 & $\bullet$ \\
\hline Rete mirabile & 0 & • & • & $\bullet$ & 0 & - & 0 & 0 & - & 0 & 0 & 0 & - & - & $\bullet$ & 0 \\
\hline Rim & • & 0 & • & $\bullet$ & $\bullet$ & - & 0 & $\bullet$ & 0 & • & $\bullet$ & - & - & $\bullet$ & 0 & • \\
\hline Rúmen & 0 & 0 & 0 & 0 & 0 & 0 & 0 & 0 & 0 & 0 & 0 & 0 & 0 & 0 & - & 0 \\
\hline Tonsila & 0 & 0 & 0 & 0 & - & 0 & 0 & 0 & 0 & 0 & 0 & 0 & 0 & 0 & $\bullet$ & 0 \\
\hline
\end{tabular}

anão examinado, bexaminado, cintestino delgado, dintestino grosso. que foram fornecidos pelo Dr. Donal OToole ${ }^{6}$. Para extração do DNA viral foram seccionados pequenos fragmentos (cerca de $25 \mathrm{mg}$ ) de vários tecidos emblocados em parafina, prefixados em formol nãotamponado a $10 \%$ As secções foram colocadas em microtubos de 2 $\mathrm{ml}$, desparafinadas com $1200 \mu \mathrm{l}$ de xilol por $15 \mathrm{~min}$ a $55^{\circ} \mathrm{C}$, lavadas com etanol e secadas a vácuo, em temperatura ambiente. As amostras dessecadas foram suspensas em tampão de digestão (100 $\mathrm{mM} \mathrm{NaCl}, 10$ mM Tris-HCl, pH 8, 25 mM EDTA e 0,5\%SDS) com 0,5 $\mathrm{mg} / \mathrm{ml}$ de proteinase $\mathrm{K}$ e incubadas a $55^{\circ} \mathrm{C}$ por 24 horas. $O$ DNA foi purificado pelo método padrão de extração fenol/clorofórmio e precipitação com etanol (Maniatis et al. 1982). A concentração de DNA extraído foi checado em gel de agarose a 0,8\% Para amplificação do DNA de OvHV-2 utilizou-se um kit comercial Taq PCR Mix $\left(\right.$ QIAGEN) ${ }^{7}$, contendo 2 unidades de Taq DNA Polimerase, $100 \mu \mathrm{M}$ de cada dNTP, 0,25 $\mu \mathrm{M}$ de ambos primers e cerca de $0,2 \mu \mathrm{g}$ de DNA extraído. Para PCR primária foram utilizados os primers 556 (5'-AGTCTGGGTATATGAATCCAGATGGCTCTC-3') e 755 (5'AAGATAAGCACCAGTTATGCATCTGATAAA-3'). A reação seguiu 35 ciclos de 5 minutos a $94^{\circ} \mathrm{C}$ seguidos de 30 segundos a $94^{\circ} \mathrm{C}$, 30 segundos a $55^{\circ} \mathrm{C}$, 45 segundos a $72^{\circ} \mathrm{C}$; seguidos de 7 minutos a $72^{\circ} \mathrm{C}$ e repouso a 4ํ C. Para PCR secundária utilizou-se a mesma solução de reação, porém com $1 \mu \mathrm{l}$ do produto da PCR primária ao invés do DNA extraído; utilizaram-se os primers 556 e 555 (5'-TTCTGGGGTAGTGGCGAGCGAA GGCTTC-3'). A reação seguiu 35 ciclos de 5 minutos a 94을 C e então 30 segund os a $94^{\circ} \mathrm{C}$, 30 segundos a $58^{\circ} \mathrm{C}, 45$ segundos a $72^{\circ} \mathrm{C}$; seguidos de 7 minutos a $72^{\circ} \mathrm{C}$ e repouso a $40 \mathrm{C}$. Um total de $10 \mu \mathrm{l}$ de cada produto do PCR foi avaliado em gel de agarose a $2 \%$

\section{RESULTADOS}

\section{Epidemiologia}

As duas propriedades rurais (A e B) onde ocorreram os surtos de FCM são localizadas no município de Santiago, Rio Grande do Sul. Na Propriedade A, os primeiros casos ocorreram no início de novembro de 2001 e os últimos em fevereiro de 2002. Nessa propriedade havia ocorrido um surto de FCM em bovinos

\footnotetext{
${ }^{6}$ Donal O'Toole, MVB, PhD, University of Wyoming, Wyoming State Veterinary Laboratory, 1174 Snowy Range Road, Laramie, WY 82070, Estados Unidos.
}

${ }^{7}$ QiAamp, Qiagen, Inc., Valencia, CA, Estados Unidos.

Quadro 3. Dados dos 11 bovinos necropsiados nas duas propriedades de Santiago, RS, onde ocorreram os surtos de febre catarral maligna em 2001-2003

\begin{tabular}{|c|c|c|c|c|c|c|c|}
\hline Número & Protocolo & $\begin{array}{c}\text { Data da } \\
\text { necropsia }\end{array}$ & $\begin{array}{c}\text { Propriedade } \\
\text { de origem }\end{array}$ & $\begin{array}{l}\text { Idade } \\
\text { (anos) }\end{array}$ & Raça & $\begin{array}{c}\text { Tipo de } \\
\text { morte }\end{array}$ & $\begin{array}{l}\text { Evolução da } \\
\text { doença (dias) }\end{array}$ \\
\hline $01^{a}$ & Vn-295-01 & 23.11 .01 & A & 4 & $T x C^{b}$ & Eutanásiac $^{c}$ & 5 \\
\hline 02 & Vn-296-01 & 23.11 .01 & A & 4 & $\mathrm{TxC}$ & Eutanásia & 5 \\
\hline 03 & Vn-305-01 & 29.11 .01 & A & 4 & $\mathrm{TxC}$ & Espontânea & 4 \\
\hline 04 & Vn-321-01 & 18.12 .01 & A & 5 & $\mathrm{TxC}$ & Eutanásia & 5 \\
\hline 05 & Vn-330-01 & 21.12 .01 & A & 3 & $\mathrm{TxC}$ & Eutanásia & 8 \\
\hline 06 & Vn-016-02 & 21.01 .02 & A & 10 & Charolês & Eutanásia & 4 \\
\hline 07 & Vn-026-02 & 01.02 .02 & A & 5 & $\mathrm{Nx} \mathrm{C}^{\mathrm{d}}$ & Espontânea & 3 \\
\hline 08 & Vn-029-02 & 02.02 .02 & A & 4 & $\mathrm{TxC}$ & Eutanásia & 2 \\
\hline 09 & V-75-02 & 23.02 .02 & A & 4 & $\mathrm{TxC}$ & Espontânea & 2 \\
\hline 10 & V-012-03 & 07.01 .03 & B & 3 & SRD & Espontânea & 3 \\
\hline 11 & Vn-032-03 & 31.01 .03 & B & 4 & SRD & Eutanásia & 4 \\
\hline
\end{tabular}

a Nove bovinos eram fêmeas e um (Bov.10) era macho, bcruza Tabapuã com Charolês, ctodos os bovinos foram sacrificados in extremis, ${ }^{d}$ cruza Nelore com Charolês, esem raça definida. 
no verão de 1994/95 quando 29 de 470 vacas foram afetadas e morreram (Barros 1994). Os bovinos afetados em 1994/5 e em 2001/02 estavam em pastagens onde havia ovinos consorciados com os bovinos. Em 2001/02, havia numa invernada de 200 hectares, 170 vacas adultas jovens, cruzas de raças zebuínas com charolês. O proprietário informou que, pelo menos, quatro ovelhas estiveram junto com as vacas nessa invernada e que essas ovel has haviam parido no inverno anterior (aprox. 4-5 meses antes do início do surto de 2001/2). A idade das 170 vacas variava de 3-5 anos, com predominância de vacas de 4 anos. Apenas uma vaca mais velha (10 anos) fazia parte desse lote. Segundo informações do proprietário, das 170 vacas 18 adoeceram (morbidade de 10,59\% e 15 morreram (letalidade de 83,33\%. Nove foram necropsiadas (Quadro 3).

Na Propriedade B, os casos de FCM ocorreram em janeiro e fevereiro de 2003. De um total de 500 bovinos com 3-4 anos de idade, 12 adoeceram (morbidade de 2,4\% e morreram (letalidade de $100 \%$. Desses 12 bovinos, dois foram necropsiados (Quadro 3). Na Propriedade B, os bovinos estiveram em contato com borregas na mesma invernada durante os 60 dias que precederam o início do surto. Não houve contato com ovelhas em parição nessa propriedade. Nos dois estabelecimentos rurais, a doença apresentou um curso clínico agudo a subagudo. Desde a primeira observação dos sinais clínicos até a morte espontânea ou por eutanásia in extremis, a evolução da doença variou de 2 a 8 dias.

\section{Sinais clínicos}

Os principais sinais clínicos estão resumidos no Quadro 4. Foram computados somente os sinais clínicos observados nos animais que foram necropsiados. Em geral, os sinais iniciavam com apatia, leve corrimento nasal, corrimento ocular seroso (Fig. 1) e febre. 0 agravamento desses sinais era rápido e complicado por sinais neurológicos e diarréia, culminando, na grande maioria dos casos, em morte. Observou-se febre em todos os

Quadro 4. Sinais clínicos em 11 bovinos afetados por febre catarral maligna nos surtos espontâneos ocorridos emSantiago, RS, 2001-2003

\begin{tabular}{|c|c|c|c|c|c|c|c|c|c|c|c|}
\hline \multirow[t]{2}{*}{ Sinal clínico } & \multicolumn{11}{|c|}{ Bovino } \\
\hline & 1 & 2 & 3 & 4 & 5 & 6 & 7 & 8 & 9 & 10 & 11 \\
\hline Febre & - a & - & n.a.b & n.a. & n.a. & - & & - & n.a. & n.a. & - \\
\hline Corrimento nasal & • & - & - & - & - & - & & - & - & - & - \\
\hline Distúrbios nervosos & - & - & - & $0^{C}$ & 0 & - & 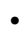 & - & - & - & - \\
\hline Corrimento ocular & $\bullet$ & 0 & • & $\bullet$ & $\bullet$ & - & 0 & 0 & 0 & • & • \\
\hline Opacidade da córnea & - & 0 & 0 & 0 & - & - & 0 & - & 0 & 0 & - \\
\hline Diarréia & 0 & 0 & 0 & $\bullet$ & $\bullet$ & 0 & 0 & 0 & 0 & $\bullet$ & $\bullet$ \\
\hline Sialorréia & 0 & 0 & 0 & - & - & 0 & 0 & • & 0 & 0 & 0 \\
\hline $\begin{array}{l}\text { Erosões e corrimento } \\
\text { vulvar }\end{array}$ & 0 & 0 & 0 & 0 & 0 & - & 0 & • & 0 & 0 & 0 \\
\hline Hematúria & 0 & 0 & 0 & 0 & • & 0 & 0 & 0 & • & 0 & 0 \\
\hline
\end{tabular}

apresente, bnão avaliado, causente.

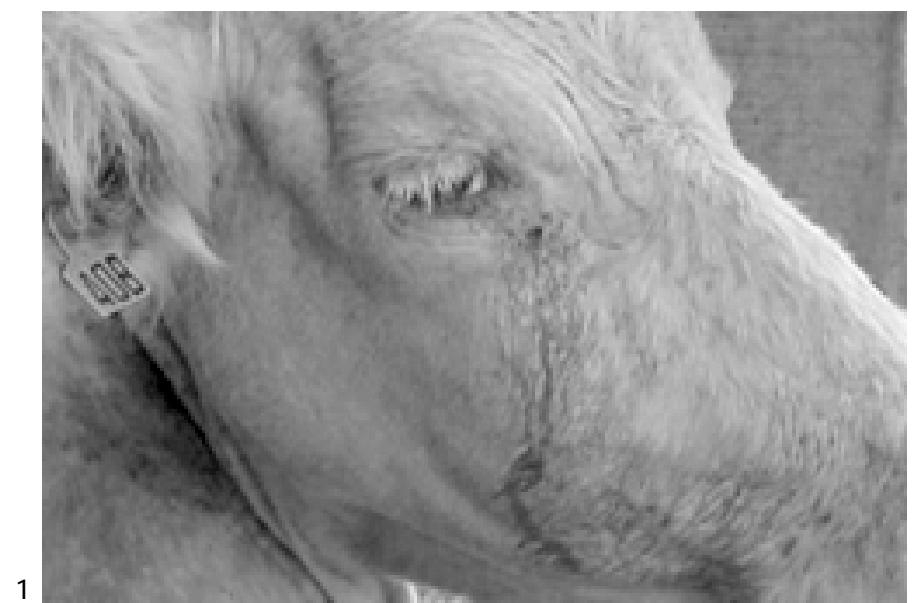

1

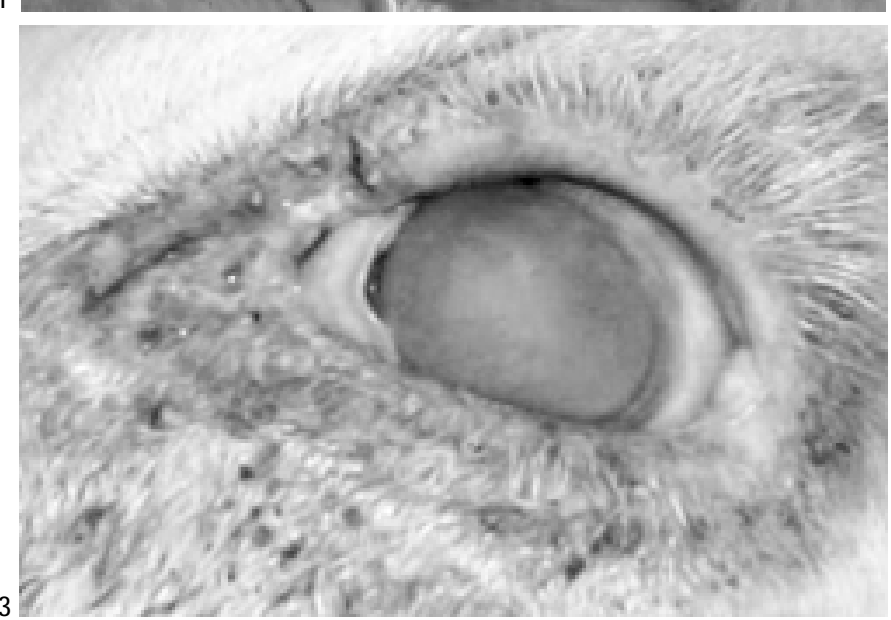

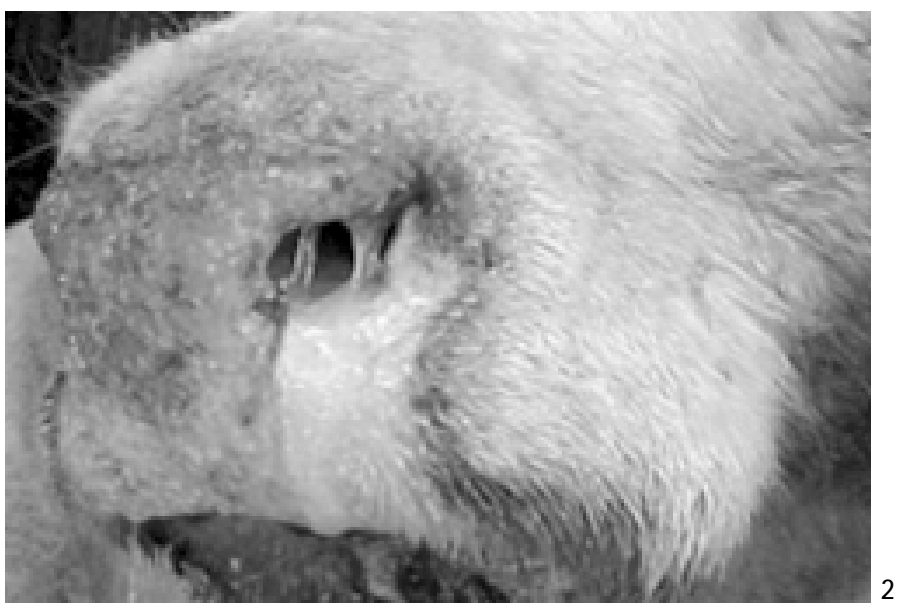

Fig.1. Corrimento ocular seroso em caso espontâneo de febre catarral maligna (Bovino 4).

Fig. 2. Corrimento nasal mucopurulento nas narinas de caso espontâneo de febre catarral maligna (Bovino 4).

Fig. 3. Opacidade da córnea em caso espontâneo de febre catarral maligna (Bovino 6). 
bovinos em que a temperatura corporal foi aferida (6/6) com temperaturas corporais variando entre 40,5 e $41,5^{\circ} \mathrm{C}$. Corrimento nasal seroso que evoluía para mucoso ou mucopurulento foi observado em todos os bovinos afetados (Fig. 2). Lesões oculares, características da forma "cabeça-e-olho", foram observadas freqüentemente (6/11) e consistiam predominantemente de opacidade de córnea (Fig. 3) hiperemia das conjuntivas e esclera. Os bovinos com intensa opacidade de córnea estavam cegos. Hipópion ou hifema foi observado em dois bovinos (Bov. 7 e 11).

Uma manifestação clínica quase constante nos dois surtos (9/11) consistiu de distúrbios nervosos que variavam de intensidade de acordo com o estágio da doença. Consistiam desde apatia, leve incoordenacão ou ataxia acentuada, hipermetria, opistótono, tremores e freqüentes episódios convulsivos. Três bovinos (Bov. 2, 7 e 8) apresentaram agressividade. Os Bovinos 1, 3 e 6 apresentaram dispnéia e estertor em conseqüência da obstrução das vias respiratórias superiores.

Na fase final da doença, as fezes tornavam-se pastosas e diarréia profusa ocorreu em 4 dos 11 bovinos examinados. Três bovinos apresentaram intensa salivação, em conseqüência das lesões erosivo-ulcerativas na mucosa oral. Outros sinais menos freqüentes incluíram hematúria (2/11), corrimento vulvar mucopurulento acompanhada de erosões, ulcerações e miíase na mucosa (2/11), crostas e erosões na pele da região do lombo e flanco, desidratação, inapetência e caquexia (1/11).

\section{Achados de necropsia}

Os principais achados de necropsia incluíam lesões nos tratos digestivo, respiratório superior e urinário. Além disso, as alterações o culares observadas clinicamente foram confirmadas na necropsia. Erosões e ulcerações ocorreram na mucosa da cavidade oral de três dos nove bovinos. As lesões erosivoulcerativas da cavidade oral incluíam almofada dental, língua e gengiva ocasionando, por vezes, grandes áreas de desprendimento do epitélio. Na mucosa das bochechas havia erosões e necrose das papilas sensitivas em três dos 9 bovinos. Erosões e úlceras foram observadas na mucosa do abomaso de sete bovinos e na mucosa intestinal de quatro.

No trato respiratório superior as lesões incluíam hiperemia e exsudato catarral nas fossas nasais, ocasionalmente acompanhados de petéquias, erosões e úlceras da mucosa das narinas. Hiperemia, erosões ou ulcerações de até $1 \mathrm{~cm}$ de diâmetro recobertas por placas diftéricas ou exsudato purulento estavam presentes nos cornetos nasais de seis bovinos. Havia tampões de exsudato catarral ou fibrinopurulento na luz da traquéia, brônquios e porção inicial dos bronquíolos de dois bovinos (Bov. 2 e 5) ou petéquias e víbices na mucosa da traquéia e brônquios de outros dois (Bov. 7 e 8 ).

Nefrite intersticial, representada por múltiplos focos pálidos na superfície natural e de corte (Fig. 4), foi observada na maioria dos bovinos (7/9). Esses focos pálidos localizavam-se predominantemente no córtex renal, eram branco-amarelados, com 2 a $4 \mathrm{~mm}$ de diâmetro e ocasionalmente apresentavam um pequeno orifício central, correspondente a uma artéria de pequeno calibre. Na bexiga as lesões também foram freqüentes (7/9) e caracterizadas por edema acentuado da parede, petéquias e equimoses na mucosa.
Os linfonodos mesentéricos estavam ocasionalmente aumentados de volume e ao corte tinham a superfície irregular, edematosa ou hemorrágica (Bov. 4-8). Na superfície de corte dos linfonodos retrofaríngeos, prescapulares e ilíacos do Bovino 11 observavam-se proliferações nodulares claras de 2 a $4 \mathrm{~mm}$ de diâmetro concentradas na região medular (hiperplasia linfóide). As leptomeninges estavam difusamente hiperêmicas nos Bovinos 2, 5 e 8. Lesões infreqüentes incluíram erosões lineares na mucosa do esôfago e corrimento uterino catarral com ulceração focal na vulva (Bov. 6 e 8).

\section{Achados histológicos}

$\mathrm{Na}$ histologia, observaram-se infiltrados inflamatórios mononucleares perivasculares, necrose do epitélio de revestimento e, especialmente, vasculite fibrinóide em múltiplos órgãos e tecidos. A intensidade das lesões vasculares variou desde mínimo infiltrado linfocítico na adventícia até extenso comprometimento transmural. Essas lesões eram comumente observadas em artérias e arteríolas dos rins, bexiga, cornetos nasais, encéfalo e retemirabilecarotídea (Fig. 5). Consistiam de infiltrado inflamatório mononuclear na parede, predominantemente na adventícia, estendendo-se para os espaços perivasculares. Necrose fibrinóide focal ou segmentar era ocasionalmente observada na túnica média das artérias de médio e pequeno calibre do rim (Fig. 6). Ocasionalmente observava-se obliteração da luz vascular devido ao intenso infiltrado inflamatório transmural, com tumefação e hiperplasia de células endoteliais e miócitos e infiltrado inflamatório naíntima.

As células inflamatórias eram compostas predominantemente por linfócitos, e outras células mononucleares indistintas, com moderado pleomorfismo, núcleos vesiculares ou moderadamente corados. Ocasionalmente eram observados plasmócitos e macrófagos, e, raramente, neutrófilos. No interstício, essas células formavam acúmulos de intensidade variada, geral mente próximos a vasos.

As lesões oculares incluíram vasculite, edema, hemorragia, ceratite, uveíte e conjuntivite. A córnea estava espessada com separação das fibras estromais por edema e leve infiltrado mononuclear e neutrofílico. Em alguns casos havia ulceração do epitélio, tumefação das células epiteliais remanescentes e neovascularização. Intensa congestão e hemorragia eram freqüentemente observadas no corpo ciliar e íris. Hemorragia na câmara anterior foi observada em um bovino. As lesões inflamatórias mais acentuadas com vasculite necrosante concentravam-se no limbo, esclera, episclera, conjuntiva bulbar e íris. Os vasos da retina e corpo ciliar eram menos afetados. Nos casos mais graves observava-se vasculite circunjacente ao nervo óptico, corpo ciliar, limbo e ocasionalmente na esclera, córnea e conjuntiva. Linfócitos, macrófagos, neutrófilos e alguns plasmócitos infiltravam difusamente o interstício. Em um bovino a câmara anterior esta repleta por placa de material fibrilar protéico com poucas células mononucleares e neutrófilos (hipópion fibrinoso).

As lesões epiteliais incluíram necrose com erosão e/ou ulceração, acompanhadas de infiltrado inflamatório mononuclear semelhante ao infiltrado observado nos vasos. Eram invariavelmente acompanhadas de vasculite leve a moderada nas camadas 

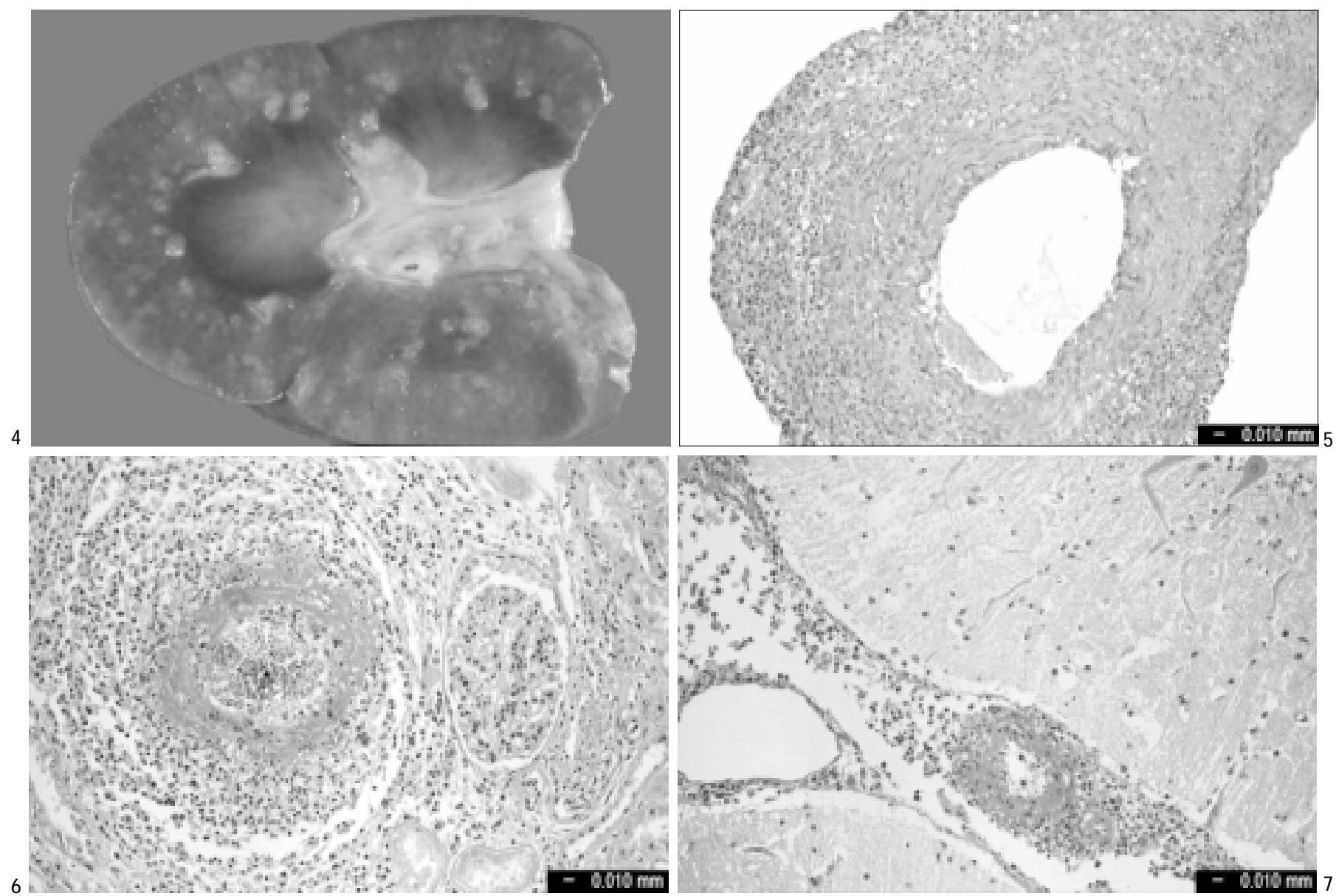

Fig. 4. Caso espontâneo de febre catarral maligna (Bovino 1). $\mathrm{Na}$ superfície de corte do rim há múltiplos nódulos brancos de alguns milímetros de diâmetro distribuídos pela cortical. No centro de alguns desses pequenos nódulos pode-se perceber um orifício. Esses nódulos representam acúmulos de células inflamatórias mononucleares ao redor de pequenas artérias (ver Fig. 6).

Fig. 6. Febre catarral maligna. Aspecto histológico das lesões renais (Bovino 1). Há necrose fibrinóide acentuada e moderado infiltrado mononuclear da túnica média de artéria de pequeno calibre e extenso infiltrado mononuclear na adventícia e tecido renal perivascular. HE, obj. 20.

subjacentes. Ocorriam ao longo do trato gastrintestinal, respiratório superior e bexiga. Na mucosa oral, especialmente na bochecha e lábios, havia erosões e úlceras, e a submucosa subjacente estava infiltrada por células inflamatórias predominantemente mononucleares. No trato gastrintestinal as lesões erosivoulcerativas estavam presentes no abomaso e intestino delgado. Ocasionalmente havia hemorragia e edema na submucosa com infiltrado difuso intersticial e vasculite na lamina própria e submucosa. Nos cornetos nasais as lesões variaram desde leve congestão e hemorragia até acentuadas ulcerações acompanhadas de infiltrado difuso na submucosa. Em dois bovinos (Bov. $4 \mathrm{e}$

Fig. 5. Febre catarral maligna em bovinos. Aspecto histológico das lesões vasculares na rete mirabile carotídea. Acentuado infiltrado inflamatório mononuclear na parede de artéria da rete mirabile (Bovino 4). Embora as células inflamatórias afetem predominantemente a adventícia, o infiltrado estende-se também para a túnica média. HE, obj. 20.

Fig. 7. Febre catarral maligna (Bovino 1). Aspecto histológico do córtex e meninges do cerebelo. As leptomeninges estão infiltradas por células mononucleares. Em uma artéria de pequeno calibre e uma arteríola meníngeas localizadas na porção inferior e ao centro da ilustração, a túnica média tem aspecto fibrinóide e está moderadamente infiltrada por células inflamatórias mononucleares; a adventícia desses vasos está acentuadamente infiltrada pelo mesmo tipo de células inflamatórias. HE, obj. 20.

11) as arteríolas da submucosa estavam intensamente afetadas, com acúmulo de restos celulares e material eosinofílico fibrinóide e infiltrado inflamatório na adventícia e média. Na bexiga havia erosões e ulceração do epitélio. Na lâmina própria e submucosa havia intensa hemorragia e infiltrado inflamatório mononuclear. Freqüentemente observava-se edema acentuado na submucosa e muscular superficial, com vasculite fibrinóide acentuada.

A intensidade das lesões no sistema nervoso central (SNC) variava de acordo com a região anatômica afetada. As lesões mais proeminentes eram encontradas nos vasos da leptomeninge e espaços de Virchow-Robin. Consistente infiltrado perivascular 
e vasculite foram observados nas meninges cerebelares (Fig.7) acompanhadas de lesões semelhantes, porém menos acentuadas no parênquima, especialmente na substância branca. Os vasos mais afetados apresentavam 4 a 6 camadas de células inflamatórias a partir da adventícia.

As lesões nos linfonodos consistiam de congestão, hemorragia, edema e vasculite necrosante, ocasional mente acompanhada de depleção linfóide. Os seios e cordões medulares estavam ocasionalmente expandidos por macrófagos e linfócitos. Hiperplasia de células linfocíticas e reticuloendoteliais foi raramente observada.

\section{Transmissão experimental}

Quatro dos cinco bovinos inoculados manifestaram sinais clínicos compatíveis com FCM após período de incubação que variou de 15 a 27 dias. Três desses quatro bovinos morreram espontaneamente e um foi sacrificado in extremis. A evolução do quadro clínico nesses quatro animais foi de 3 dias a 8 semanas. O quinto bovino (E5) mostrou sinais clínicos leves, recuperou-se e foi submetido à eutanásia 14 semanas após a inoculação (Quadro 5).

Dois dos bezerros com FCM transmitida experimentalmente (E1 e E2) mostraram sinais clínicos de distúrbios nervosos. 0 Bovino E1 manifestou incoordenação, agressividade e convulsões que se repetiam com maior freqüência após estímulo e ocasionais quedas seguidas de movimentos de pedalagem e tremores musculares intermitentes. Três dias após o início dos sinais clínicos, esse bezerro não conseguia levantar, apresentava movimentos de pedalagem (Fig. 8) e opistótono (Fig. 9). O Bovino E2 mostrou os mesmos sinais que E1, com exceção de agressividade e com adição de pressão da cabeça contra objetos, ranger de dentes e nistagmo. No estágio terminal permanecia em decúbito lateral.

Quatro dos cinco bovinos dos experimentos de transmissão de FCM apresentaram alterações de necropsia compatíveis com FCM. Não foram observadas alterações macroscópicas na necropsia do Bovino E5. Na pele do Bovino E2 havia erosões na região periocular e os pêlos da região infraorbital estavam co-

Quadro 5. Período de incubação, evolução clínica, tipo de morte e principais achados clínicos nos cinco bovinos experimentais inoculados com $500 \mathrm{ml}$ de sangue colhido de bovino clinicamente afetado por febre catarral maligna

\begin{tabular}{|c|c|c|c|c|c|}
\hline \multirow[t]{2}{*}{ Observação } & \multicolumn{5}{|c|}{ Bovino } \\
\hline & E1 & E2 & E3 & E4 & E5 \\
\hline Período de incubação & 27 dias & 15 dias & 15 dias & 17 dias & 20 dias \\
\hline Curso clínico & 3 dias & 4 dias & 10 dias & 8 semanas & 6 semanas \\
\hline Desenlace & Eutanásiaa & Morte espontânea & Morte espontânea & Morte espontânea & Eutanasiab \\
\hline \multirow[t]{8}{*}{ Sinais clínicos } & Corrimento & Corrimento & Apatia & Corrimento ocular & Corrimento \\
\hline & nasal e ocular & nasal e ocular & Corrimento & Diarréia & nasal e ocular \\
\hline & Opacidade de córnea & Febre $\left(41^{\circ} \mathrm{C}-41,5^{\circ} \mathrm{C}\right)$ & nasal e ocular & & Fezes pastosas \\
\hline & Dispnéia & Distúrbios nervosos & Opacidade de córnea & & a diarréicas \\
\hline & Salivação & & Hifema & & Perda de peso \\
\hline & Febre $\left(41^{\circ} \mathrm{C}-41,5^{\circ} \mathrm{C}\right)$ & & Linfadenopatia & & \\
\hline & Distúrbios nervosos & & Diarréia & & \\
\hline & & & Febre $\left(41,5^{\circ} \mathrm{C}\right)$ & & \\
\hline
\end{tabular}

\footnotetext{
a Eutanásia in extremis.

b Eutanásia 14 semanas após a inoculação e cerca de 8 semanas após a recuperação.
}

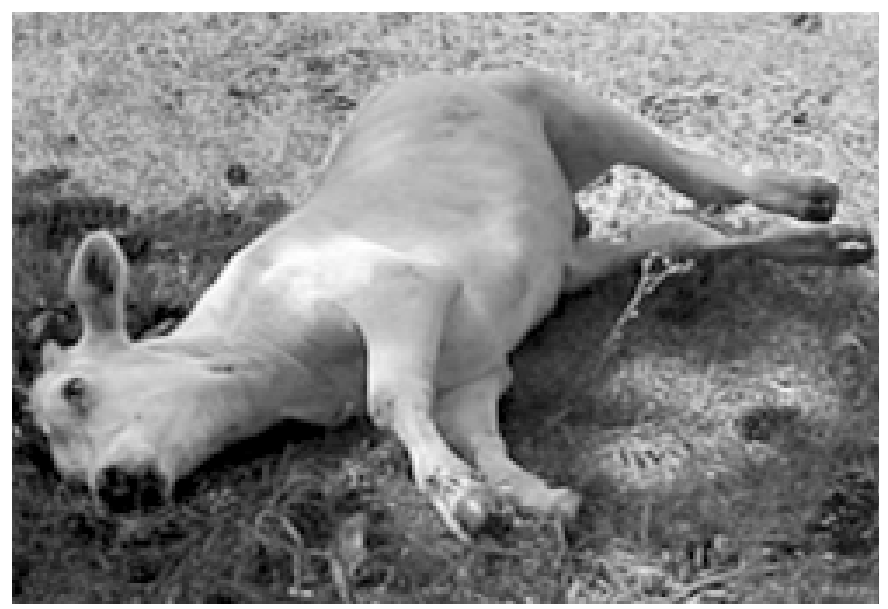

Fig. 8. Sinais clínicos de distúrbios nervosos nos casos experimentais de febre catarral maligna. Bovino E1 mostrando convulsões nas fases terminais da doença.

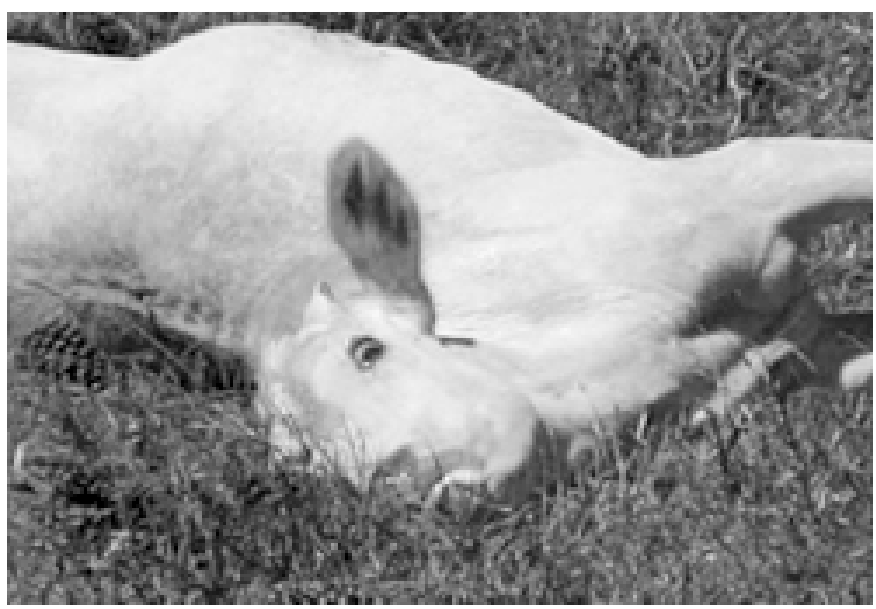

Fig. 9. Sinais clínicos de distúrbios nervosos nos casos experimentais de febre catarral maligna. Bovino E1 em opistótono. 
bertos por exsudato ressecado. Opacidade da córnea foi observada nos Bovino E1 e E3. Hiperemia da conjuntiva ocorreu no Bovino E3. Os linfonodos prescapulares (Bov. E2 e E3), faríngeos, mesentéricos e ilíacos (Bov. E3) estavam aumentados de volume (Bov. E2 e E3) e firmes (Bov. E3), com nódulos brancos de 2 a 3 $\mathrm{mm}$ de diâmetro tanto na cortical como na medular (Bov. E2 e E3). Discretas erosões recobertas por fibrina foram observadas nos cornetos nasais do Bovino E1. No Bovino E2, os cornetos nasais estavam avermelhados e havia exsudato mucoso na cavidade nasal. Discretas erosões na superfície distal da língua e de outras regiões da cavidade oral foram observadas no Bovino E4. As alterações na mucosa do esôfago foram vistas em três bovinos (E2-E4) e consistiam de erosões ou ulcerações. Ulcerações e erosões também foram observadas na mucosa do rúmen do Bovino E4 e no abomaso do Bovino E1. A mucosa do cólon do Bovino E3 estava avermelhada e havia erosões e ulcerações na mucosa de toda a extensão intestinal do Bovino E4. Nódulos branco-amarelados, multifocais, de 2 a $5 \mathrm{~mm}$ de diâmetro distribuíam-se no córtex renal do Bovino 1 e petéquias foram observadas na mucosa da bexiga do Bovino E2.

Alterações histológicas compatíveis com FCM, semelhantes aos casos naturais da doença, foram encontradas em três bovinos inoculados (E1-E3). A primeira passagem do vírus produziu as lesões histológicas mais acentuadas, caracterizadas por vasculite, inflamação intersticial e necrose epitelial.

As lesões vasculares no SNC eram semelhantes às observadas nos casos naturais e foram mais acentuadas nos Bovinos E1 e E2 e eram mais proeminentes nos vasos da meninge do cerebelo.
Infiltrados perivasculares e meníngeos eram também observados em vários locais do SNC e rete mirabile carotídea desses dois bovinos. A intensidade e distribuição das lesões vasculares no SNC em comparação aos sinais clínicos de distúrbios nervosos aparecem no Quadro 6. Lesões vasculares foram observadas ainda nas arteríolas renais (Bov. E1 eE5), no plexo pampiniforme (Bov. E2) e no globo ocular e tecidos perioculares (Bov. E2). No córtex renal havia extensos acúmulos intersticiais de células inflamatórias ao redor dos vasos de maior calibre e estendendo-se para os espaços perivasculares. 0 infiltrado era discreto ao redor de glomérulos. As lesões oculares consistiram de infiltrado inflamatório moderado focalmente extenso de células mononucleares no estroma da córnea e no processo ciliar; as células inflamatórias ocasionalmente circundavam ou infiltravam a adventícia de vasos do processo ciliar. Lesões vasculares características de FCM não foram observadas em nenhum dos tecidos examinados do Bovino E4.

Os focos esbranquiçados vistos macroscopicamente nos linfonodos dos Bovinos E2 e E3 correspondiam a nódulos de hiperplasia linfocítica. Áreas hemorrágicas e proliferação multifocal de macrófagos e linfócitos foram observadas no Bovino E2. Ao contrário da hiperplasia linfóide característica da FCM, observou-se depleção nos linfonodos e baço do Bovino E4. No Bovino E2 acúmulos multifocais de células inflamatórias ocorreram na lâmina própria dos cornetos nasais e havia moderada a acentuada necrose fibrinóide na parede dos vasos da lâmina própria, com leve a moderado infiltrado inflamatório na adventícia. 0 epitélio dos cornetos do Bovino El estava ulcerado, com

Quadro 6. Correlação dos sinais clínicos de distúrbios nervosos com a localização e intensidade das lesões vasculares no sistema nervoso central (SNC) e rete mirabile carotídea em dois bovinos experimentais inoculados com $500 \mathrm{ml}$ de sangue colhido de bovino clinicamente afetado por febre catarral maligna

\begin{tabular}{|c|c|c|c|c|c|c|c|c|c|}
\hline \multirow[t]{2}{*}{ Bovino } & \multirow[t]{2}{*}{ Distúrbio nervoso } & \multicolumn{8}{|c|}{ Localização das lesões no SNCa } \\
\hline & & 0 & 1 & 2 & 3 & 4 & 5 & 6 & $\begin{array}{c}\text { Rete } \\
\text { mirabile }\end{array}$ \\
\hline E1 & $\begin{array}{l}\text { Agressividade } \\
\text { Convulsões } \\
\text { Incoordenação } \\
\text { Opistótono } \\
\text { Pedalagem } \\
\text { Quedas } \\
\text { Tremores musculares }\end{array}$ & $(+)^{b}$ & $(+)$ & +++ & $(+)+$ & $(+)+$ & $(+)+$ & $(+)+$ & $(+)+$ \\
\hline E2 & $\begin{array}{l}\text { Bruxismo } \\
\text { Convulsões } \\
\text { Incoordenação } \\
\text { Nistagmo } \\
\text { Opistótono } \\
\text { Pedalagem } \\
\text { Quedas } \\
\text { Pressão da cabeça } \\
\text { Tremores musculares }\end{array}$ & - & - & +++ & $(+)+$ & $(+)+$ & ++ & $(+)+$ & $(+)$ \\
\hline
\end{tabular}

\footnotetext{
as números correspondem as seguintes regiões do SNC: 0 , medula cervical; 1 , seção do bulbo na altura do óbex; 2 , cerebelo; 3 , ponte com pedúnculos cerebelares; 4 , mesencéfalo na altura dos colículos rostrais; 5 , seção através do diencéfalo na altura da massa intermédia; e 6 , seção através do joelho do corpo caloso e dos núcleos basais.

b(+) Lesão discreta, (+)+ discreta a moderada, ++ moderada, + + + acentuada, - ausente.
} 
Quadro 7. Resultado da técnica de reação em cadeia de polimerase (PCR) realizada em amostras de tecido de 16 bovinos. Os bovinos de 1 a 11 são casos espontâneos de febre catarral maligna. Cinco bovinos (E1-E5) são os animais usados no estudo de transmissão experimental

\begin{tabular}{|c|c|c|c|c|c|c|c|c|c|c|c|c|c|c|c|c|c|c|}
\hline \multirow[t]{2}{*}{ Órgão } & \multicolumn{16}{|c|}{ Bovino } & \multirow{2}{*}{$\begin{array}{c}\text { Tecidos } \\
\text { positivos/tecidos } \\
\text { examinados }\end{array}$} & \multirow{2}{*}{$\begin{array}{l}\text { Porcentagem } \\
\text { de positivos }\end{array}$} \\
\hline & 1 & 2 & 3 & 4 & 5 & 6 & 7 & 8 & 9 & 10 & 11 & E1 & E2 & E3 & E4 & E5 & & \\
\hline Abomaso & $0^{a}$ & 0 & 0 & 0 & 0 & 0 & 0 & $-b$ & 0 & 0 & 0 & 0 & 0 & 0 & 0 & 0 & $0 / 1$ & 0 \\
\hline Adrenal & 0 & 0 & 0 & 0 & 0 & 0 & 0 & $+c$ & 0 & 0 & - & 0 & 0 & 0 & 0 & 0 & $1 / 2$ & 50 \\
\hline Baço & 0 & 0 & 0 & 0 & - & 0 & + & 0 & 0 & - & 0 & 0 & 0 & 0 & - & - & $1 / 5$ & 20 \\
\hline Bexiga & 0 & 0 & 0 & 0 & 0 & 0 & - & - & + & 0 & - & 0 & 0 & - & 0 & 0 & $1 / 5$ & 20 \\
\hline Bochecha & 0 & 0 & 0 & 0 & 0 & 0 & 0 & - & 0 & 0 & 0 & 0 & 0 & 0 & 0 & 0 & $0 / 1$ & 0 \\
\hline Cornetos & 0 & 0 & 0 & - & 0 & 0 & 0 & 0 & 0 & 0 & 0 & + & + & - & 0 & 0 & $2 / 4$ & 50 \\
\hline Encéfalo & 0 & + & - & 0 & - & 0 & 0 & 0 & - & + & 0 & + & 0 & + & 0 & 0 & $4 / 7$ & 57 \\
\hline Fígado & - & 0 & 0 & 0 & 0 & 0 & 0 & - & - & + & - & + & 0 & - & - & - & $2 / 9$ & 22 \\
\hline Focinho & 0 & 0 & 0 & 0 & 0 & 0 & 0 & 0 & - & 0 & - & 0 & 0 & 0 & 0 & 0 & $0 / 2$ & 0 \\
\hline Int. delgado & 0 & 0 & 0 & - & 0 & - & 0 & 0 & 0 & 0 & - & 0 & 0 & - & 0 & 0 & $0 / 4$ & 0 \\
\hline Int. grosso & 0 & 0 & 0 & 0 & - & 0 & 0 & 0 & 0 & 0 & 0 & 0 & 0 & 0 & 0 & 0 & $0 / 1$ & 0 \\
\hline Língua & 0 & 0 & 0 & 0 & 0 & 0 & 0 & 0 & 0 & 0 & 0 & 0 & 0 & 0 & - & 0 & $0 / 1$ & 0 \\
\hline Linfonodo & 0 & 0 & - & 0 & - & + & 0 & + & 0 & 0 & - & 0 & 0 & 0 & 0 & - & 26 & 33 \\
\hline Rete mirab ${ }^{d}$ & 0 & - & - & - & 0 & - & 0 & 0 & - & 0 & 0 & 0 & + & - & - & 0 & $1 / 8$ & 12,5 \\
\hline Rim & - & 0 & - & + & - & + & 0 & - & 0 & - & - & + & + & - & 0 & - & $4 / 12$ & 33 \\
\hline Rúmen & 0 & 0 & 0 & 0 & 0 & 0 & 0 & 0 & 0 & 0 & 0 & 0 & 0 & 0 & - & 0 & $0 / 1$ & 0 \\
\hline Tonsila & 0 & 0 & 0 & 0 & - & 0 & 0 & 0 & 0 & 0 & 0 & 0 & 0 & 0 & - & 0 & $0 / 2$ & 0 \\
\hline
\end{tabular}

aNão examinado, bnegativo para OvHV-2, cpositivo para OvHV-2, dRete mirabile carotídea.

infiltrado mononuclear inflamatório moderado difuso na submucosa.

Havia erosão do epitélio de revestimento da bochecha do Bovino El com infiltrado difuso e acentuado de células inflamatórias mononucleares na submucosa superficial. Lesões erosivoulcerativas associadas a infiltrado mononuclear da submucosa eram observadas na mucosa oral e língua, esôfago e rúmen (Bov. E4) e mucosa esofagiana do Bovino E3. Leve infiltrado mononuclear foi observado nos espaços-porta do fígado dos

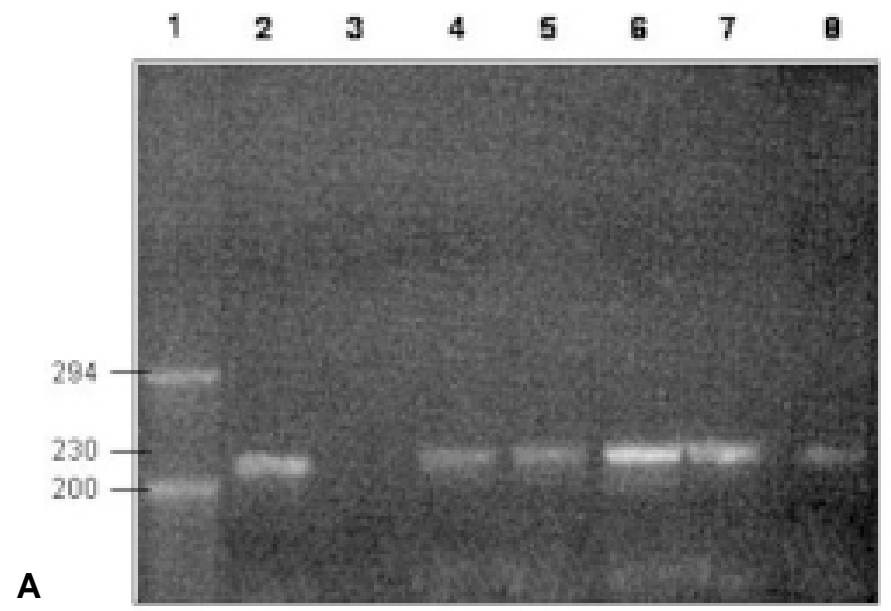

Bovinos E1 eE5. No intestino havia leve infiltrado intersticial e vasculite na submucosa e muscular (Bov. E2).

Infiltrado mononuclear foi observado no interstício da tireóide (Bov. E1). Na bexiga do Bovino E2 havia ulceração multifocal do epitélio de transição com infiltrado mononuclear na lâmina própria subjacente; infiltrado mínimo de células mononucleares ocorria na parede dos vasos da lâmina própria e submucosa associado a edema na muscular da mucosa e submucosa.

Fragmentos de tonsila do Bovino E4 resultaram negativos

Fig. 10. Reação em cadeia de polimerase (PCR). Eletroforese em gel de agarose dos produtos da PCR nested mostrando fragmentos amplificados de 228 pares de bases (pb).

(A) Casos espontâneos. Linha 1: tamanho molecular padrão (pb). Linha 2: amostra de adrenal (Bov. 8). Linha 3: amostra de linfonodo (Bov. 8) Linha 4: amostra de baço (Bov. 7). Linha 5: amostra de rim (Bov. 6). Linha 6: amostra de linfonodo (Bov. 6). Linha 7: amostra de bexiga (Bov. 9). Linha 8: amostra de cerebelo (Bov. 2).

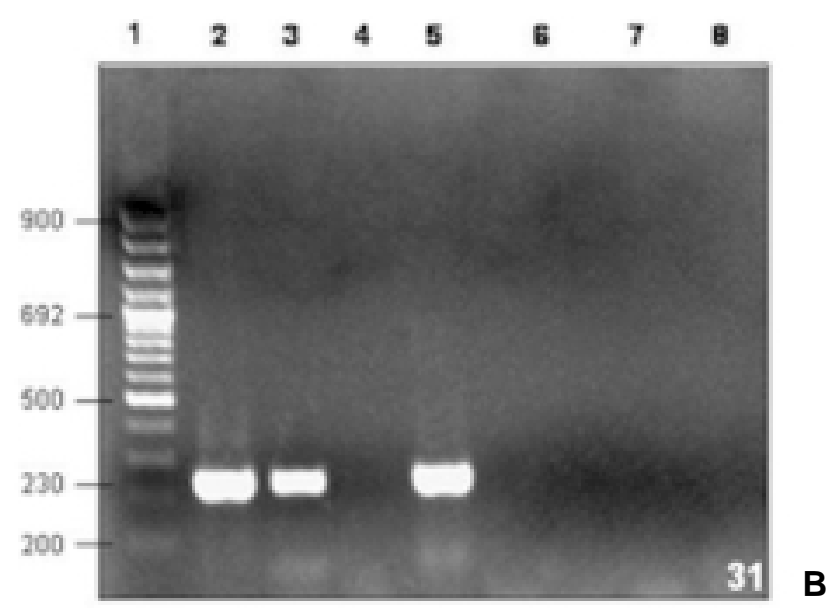

.

(B) Casos experimentais. Linha 1: tamanho molecular padrão (pb). Linha 2: amostra de rim (Bov. E1). Linha 3: amostra de fígado (Bov. E1). Linha 4: amostra de fígado (Bov. E5). Linha 5: amostra de rim (Bov. E2). Linhas 6-8: amostras de rúmen, fígado e tonsila, respectivamente (Bov. E4). 
para o vírus da diarréia viral bovina na técnica de imunoistoquímica.

\section{Reação em cadeia de polimerase (PCR)}

Dos 14 bovinos inicialmente diagnosticados com FCM pelo critério clinicopatológico, $10(71,42 \%$ foram positivos para OvHV2 na técnica de PCR nested (Quadro 7, Fig.10). Todos os casos positivos na PCR foram compatíveis com o diagnóstico histológico positivo. Seis bovinos positivos na histologia resultaram negativos na PCR; dois bovinos (E4 e E5) foram negativos em ambos os testes. Sete casos espontâneos foram positivos em um ou dois tecidos. Em relação aos casos experimentais, foram positivas todas as amostras de tecidos examinadas dos Bovinos E1 e E2 e uma amostra de tecido do Bovino E3.

Do total de 71 amostras de tecidos examinadas pela técnica de PCR, 18 foram positivas para OvHV-2. Dessas, 16 (incluindo encéfalo, rim, linfonodo, adrenal, bexiga, corneto nasal, fígado e retemirabilecarotídea) tinham lesão histológica leve ou acentuada compatível com FCM e duas (baço e linfonodo) eram de tecidos sem alterações histológicas.

\section{DISCUSSÃO}

Os sinais clínicos, os achados de necropsia e a histopatologia observados nos 11 bovinos dos surtos ocorridos nas Propriedades $A$ e $B$, são consistentes com os relatos anteriores da FCM em bovinos (Pierson et al. 1973, Selman et al. 1974, Liggitt et al. 1978, Ligitt et al. 1980a,b, Otter et al. 2002). Adicionalmente, o diagnóstico de FCM foi confirmado pela reprodução experimental da doença (Propriedade A) e pela determinação genômica de OvHV-2 nos tecidos dos bovinos afetados (Propriedades A e B). Vários surtos epizoóticos ou a ocorrência esporádica de FCM em bovinos haviam sido relatados até então no Brasil (Torres 1924, Döbereiner \& Tokarnia 1959, Sampaio et al. 1972, Oliveira et al. 1978, Barros et al. 1983, Marques et al. 1986, Riet-Correa et al. 1988, Figueiredo et al. 1990, Baptista \& Guidi 1998, Silva et al. 2001), mas os diagnósticos foram feitos com base nos sinais clínicos, nas alterações de necropsia e na histopatologia. Desse modo, até onde sabemos, este relato inclui pela primeira vez epizootias de FCM em bovinos em nosso país em que a transmissão e a técnica de PCR confirmaram casos que haviam sido diagnosticados pelos sinais clínicos, alterações de necropsia e histopatologia característicos. A confirmação de FCM através de ensaio de PCR realizada no sangue de um veado (Mazama goauzoubira) já havia sido relatada em um surto em que sete veados dessa espécie foram afetados em um zoológico de Cuiabá (Driemeier et al. 2002). Isso sugere que 0 vírus que circula e produz a doença no Brasil é OvHV-2. Tem sido demonstrado que a técnica de PCR para detecção de segmentos de DNA viral de OvHV-2 é um teste altamente sensível e específico para os casos de FCM-OA (Müller-Doblies et al. 1998, Crawford et al. 1999, Collins et al. 2000). Seqüências do vírus podem ser demonstradas em vários tecidos, especialmente no tecido linfóide (Crawford et al. 1999). O DNA de OvHV-2 é geralmente detectado nos tecidos com vasculite (Crawford et al. 1999) ou com infiltrado linfocítico (Collins et al. 2000). Neste estudo não se observou correlação entre a positividade para
PCR e a intensidade do infiltrado linfocítico nos diferentes tecidos. Tecidos de bovinos dos surtos espontâneos que resultaram negativos no teste de PCR neste estudo eram tecidos reemblocados ou emblocados em parafina após fixação em formol não-tamponado por longos períodos. Períodos de fixação superiores a 45 dias produzem resultados negativos ou fraco positivos (Crawford et al. 1999). Isso poderia explicar os casos de discordância entre os achados histopatológicos considerados patognômicos (Barker et al. 1993) encontrados nos bovinos deste estudo e os resultados da PCR. Um exemplo disso é que o Bovino 5 que foi doador do sangue para os experimentos, tinha lesões características de FCM, mas a presença do DNA viral de OvHV-2 não foi detectada em seus tecidos pela PCR. Mesmo assim, três dos bezerros que receberam o sangue propagado a partir do sangue do Bovino 5, desenvolveram FCM e tiveram a presença de OvHV-2 em seus tecidos confirmada por PCR.

A FCM-OA ocorre geralmente na forma esporádica afetando um único bovino por rebanho (Riet-Correa et al. 1988, Barker et al. 1993, Smith 2002), embora existam relatos de surtos com múltiplos casos (Torres 1924, Döbereiner \& Tokarnia 1959, Pierson et al. 1973, Barros et al. 1983, Marques et al. 1986, Hamilton 1990, Collery \& Foley 1996, Silva et al. 2001, Otter et al. 2002, Dabak \& Bulut 2003). Nos surtos descritos neste estudo nas propriedades A e B, a FCM ocorreu em surtos epizoóticos com taxas de morbidade respectivamente de 10,59\%e 2,4\%e taxas de letalidade respectivamente de $83,33 \%$ e $100 \% 0$ surto de FCM que ocorreu nos bovinos da Propriedade A em 1994 teve uma morbidade de $6,17 \%$ uma letalidade próxima a $100 \%$ A recuperação de três bovinos afetados na Propriedade A é um fato interessante. Embora no passado a doença tenha sido considerada invariavelmente fatal, a ponto de haver reformulação do diagnóstico de FCM caso o animal se recuperasse (Selman et al. 1974), sabe-se hoje que casos de recuperação não são raros e que formas crônicas de FCM são observadas (O'Toole et al. 1995, O'Toole et al. 1997, Otter et al. 2002). Foi sugerida uma tendência de os surtos de FCM-OA ocorrerem em bovinos na primavera e verão (Selman et al. 1974). Essa tendência foi também verificada nos dois surtos descritos aqui e no surto observado na Propriedade A em 1994 (Barros 1994).

0 período de incubação élongo podendo se estender de 3 a 10 semanas e a duração do curso clínico da doença aguda é de 3 a 7 dias podendo haver casos hiperagudos de um dia de evolução (Smith 2002). Sob essa óptica, nas duas epizootias relatadas neste estudo, em que a evolução da doença foi de 2 a 8 dias, os casos poderiam ser enquadrados na categoria de curso clínico agudo ou, no máximo, subagudo. Duração de curso clínicos equivalentes para a FCM em bovinos têm sido descritos (Pierson et al. 1979, Collery \& Foley 1996, Otter et al. 2002).

Um ponto a ressaltar na ocorrência de FCM em bovinos deste estudo foi a freqüência com que ocorreram sinais clínicos de distúrbios nervosos. Dos 11 bovinos examinados clinicamente com mais detalhe, apenas dois não demonstraram distúrbios neurológicos marcantes. Esseé um dado importante a ser considerado no diagnóstico diferencial de doenças do SNC em bovinos.

0 modo de disseminação do vírus da FCM-OA é pouco conhecido. Dados epidemiológicos (nem sempre convincentes) suge- 
rem que os ovinos são os portadores do vírus da FCM-OA e que excretam e transmitem o vírus para outras espécies, como, por exemplo, bovinos (Pierson et al. 1973, Selman et al. 1974, Reid et al. 1989). É proposto que a transmissão ocorra na época da parição das ovelhas à semelhança do que ocorre na transmissão do AlHV1 na FCM-GA (Rossiter 1983). No entanto, a determinação do DNA vírico por PCR na secreção nasal e nos leucócitos do sangue periférico (LSP) de ovinos (Li et al. 2001b) sugere que cordeiros recémnascidos não são fontes importantes para a transmissão de OvHV2. Nesse estudo, o DNA do vírus só foi detectado aos três meses (nos LSP) e aos cinco meses na secreção nasal. Além disso, a transmissão da doença por inoculação de tecidos de ovinos contaminados não foi ainda realizada (Plowright 1990). Há consideráveis evidências que bovinos com FCM aguda raramente transmitem a infecção para outros bovinos (Plowright 1990) e o mesmo provavelmente seja verdade para o caso de bovinos portadores recuperados (O'Toole et al. 1997), mas há algumas considerações que podem ser feitas para explicar a manutenção da doença na Propriedade A por quase uma década e 0 aparecimento da doença onde não existe o contato de bovinos com ovinos (Smith 2002). Bovinos que se recuperam de FCM permanecem cronicamente afetadose persistentemente infectados por OvHV-2 (Baxter et al. 1993, O'Toole et al. 1997). Isso sugere a possibilidade de que esses animais possam ser fonte da infecção horizontal ou vertical para outros membros do rebanho. Por outro lado, a infecção transplacentária de FCM já foi demonstrada em bovinos (Plowright et al. 1972, 0Toole et al. 1997) e bisões (Schultheiss et al. 1998). Embora não se saiba se esses fetos iriam adoecer ou se tornar portadores, essa poderia ser uma explicação hipotética para a manutenção do vírus em determinadas propriedades por longos períodos. Uma indicação para isso é que num surto de FCM-OA ocorrido na Grã-Bretanha, bezerros nascidos de vacas afetadas ou assintomáticas, mas PCR positivas para OvHV-2, desenvolveram FCM vários meses após o nascimento (Otter et al. 2002). Isso foi interpretado pelos autores como uma predisposição genética, mas poder-se-ia argumentar que se tratavam de bezerros nascidos infectados e que al gum fator desencadeante (por ex., estresse) tenha provocado o recrudescimento da doença como já foi descrito para cervídeos (Heuscheleet al. 1985) e bovinos (Rweyemamu et al. 1976, Tham 1997).

Vasculite disseminada, um achado patognomônico da FCM (Barker et al. 1993, Barnard et al. 1994) caracterizo u invariavelmente todos os casos espontâneos e experimentais neste estudo. A magnitude do infiltrado celular linfóide na adventícia teve relação direta com a intensidade das lesões na camada média dos vasos e essas eram invariavelmente acompanhadas de lesões inflamatórias na adventícia. Achados semelhantes já haviam sido relatados para a FCM de bovinos (Liggitt \& DeMartini 1980a). Lesões de vasculite foram observadas na rete mirabile carotídea de todos os bovinos que apresentaram quadro clínico neurológico neste estudo. Esse é um achado importante que permite a diferenciação da FCM de outras doenças do sistema nervoso central e é recomendável que sempre se colete, junto com o encéfalo, esse complexo vascular associado ao gânglio trigeminal e à hipófise.

A patogenia da FCM não está completamente esclarecida. A vasculite característica tem sido interpretada como uma evidên- cia de que as lesões da FCM resultam de um distúrbio imunológico induzido pelo vírus (Liggitt \& DeMartini 1980a) e não da ação citolítica direta do vírus. A lesão epitelial em vários órgãos é outra característica da doença e ocorre com infiltração do epitélio por linfócitos lembrando hipersensibilidade de contato e reação enxerto versus hospedeiro (Liggitt \& DeMartini 1980b). Sugere-se que os eventos principais na patogenia da FCM são a infecção viral e a desregulação de uma população de linfócitos. A perda da atividade linfócitos supressores facilitaria a proliferação linfóide observada na doença, enquanto que a atividade descontrolada de células NK seria responsável pela destruição tecidual (Barnard et al.1994, Smith 2002).

Foi concluído que dos cinco bezerros inoculados com $500 \mathrm{ml}$ de sangue de um bovino, apenas três deles(E1-E3) desenvolveram a doença ( $60 \%$. A conclusão foi baseada principalmente nos achados histopatológicos e na demonstração de seqüência do DNA viral de OvHV-2 nesses três bezerros. Febre e opacidade de córnea foram os sinais comuns aos três bezerros experimentais (E1-E3) e distúrbios nervosos ocorreram em dois (E1 e E2). 0 tempo de incubação foi 15 (BovinosE2 e E3) e 27 dias (Bov. E1). Esse período de incubação se aproxima mais do que é descrito para a FCMGA do que para a FCM-OA. Períodos de incubação em casos experimentais da forma africana têm sido relatados como sendo de 1163 dias (Plowright 1968), 14-46 dias e 7-18 dias (Plowright 1990). Para transmissão experimental da FCM-OA são relatados períodos de incubação de 20-36 dias (Selman et al. 1974), 19-73 dias (Liggitt et al. 1978) e 15-49 dias (Pierson et al. 1974). Os dados para 0 período de incubação da FCM experimental variam com os tipose a quantidade de material inoculado e provavelmente com outros fatores de susceptibilidade desconhecidos (Plowright 1990). É relatado que para a FCM-GA, o período de incubação é mais longo do que o da FCM-OA; a duração do curso clínico seria o inverso (Pierson et al. 1974). Para os bezerros deste estudo afetados experimentalmente, o curso clínico durou 4, 3 e 10 dias, respectivamente para os BovinosE2, E1 e E3. Provavelmente, a doença foi mais aguda nos Bovinos E1 e E2 devido aos sinais de distúrbios nervosos. Na transmissão experimental FCM-OA é descrito uma vez manifestados ossinais clínicos, a morte ou eutanásia in extremis ocorria em, no máximo cinco dias (Liggitt et al. 1978). As razões pelas quais os Bovinos E4 eE5 foram considerados negativos são as que se seguem. Ambos foram negativos na avaliação por PCR, embora em nossos casos isso não tenha sido considerado um critério definitivo pelas razões explicadas acima. O Bovino E4 apresentou uma enfermidade caracterizada por corrimento ocular e diarréia após um período de incubação de 17 dias, o que, clinicamente, seria consistente com FCM. No entanto, não foram encontradas as lesões histológicas vasculares típicas de FCM. A suspeita de diarréia viral bovina nesse caso não pôde ser confirmada pela imunoistoquímica. O Bovino E5 apresentou uma doença leve e se recuperou tendo sido sacrificado 14 semanas após a inoculação. Casos de recuperação não são incomuns na FCM-OA em bovinos e há casos de doença leve seguida de recuperação completa, recuperação com recrudescimento da doença e casos crônicos de FCM (O'Toole et al. 1995, 1997). Embora não se possa afastar definitivamente a hipótese de que o Bovino E5 constitui um desses casos de recuperação de FCM, isso é pouco provável porque esse animal não apresentou curso clínico compatível com FCM, foi 
negativo no teste de PCR enão apresentava alterações indicativas de FCM, quer na necropsia, quer no exame histológico.

0 diagnóstico diferencial de FCM em bovinos inclui outras doenças a vírus como diarréia viral bovina/doença das mucosas, língua azul, peste bovina, febre aftosa e estomatite vesicular (Smith 2002). Não há tratamento específico ou vacinas eficazes contra FCM (Plowright 1990). Alguns relatos sugerem remissão da doença após o uso de corticosteróides (OToole et al. 1995), mas casos de recrudescimento são também associados ao uso dessas drogas (Rweyemamu et al. 1976, Tham 1997). Geralmente se recomenda não colocar bovinos em contato com ovinos e isolar bovinos afetados de bovinos sadios (Otter et al. 2002). Tratamentos de suportetêm sido usados com relativo sucesso em al guns casos (Plowright 1990, OToole et al. 1997). Bovinos infectados continuam como reservatório do vírus por meses após a infecção e isso deve ser considerado no controle da doença.

Agradecimentos.- Os autores são gratos ao Professor Alexandre Mazzanti pelo auxílio na inoculação dos bovinos e à Profa. Glaucia Kommers pela realização das fotos das lesões microscópicas. A autora principal realizou parte dos seus experimentos (técnica da PCR) durante estágio no Department of Pathology da University of Georgia, com bolsa da CAPES, como parte do projeto CAPES-FIPSE 09/01.

\section{REFERÊNCIAS}

Baptista F.Q. \& Guidi P.C. 1998. FCM no estado do PR. Hora Vet., Porto Alegre, 45:33-37.

Barker I.K., Van Dreumel A.A. \& Palmer N. 1993. The alimentary system, p.1-317. In: Jubb K.V.F., Kennedy, P.C. \& Palmer N. (ed.) Pathology of Domestic Animals. Vol. 2. 4th ed. Academic Press, San Diego. 747p.

Barnard B.J.H., Van der Lugt J.J. \& Mushi E.Z. 1994. Malignant catarrhal fever, p.946-957. In: Coetzer J.A.W., Thomson G.R. \& Tustin R.C. (ed.) Infectious Diseases of Livestock with Special Reference to Southern Africa. Vol. 2. Oxford University, Cape Town. 1605p.

Barros C.S.L. 1994. Dados não publicados (Departamento de Patologia, Universidade Federal de Santa Maria, 97105-900 Santa Maria, RS).

Barros S.S., Santos M.N., Barros C.S.L. 1983. Surto de febre catarral maligna em bovinos no Rio Grande do Sul. Pesq. Vet. Bras. 3:81-86.

Baxter S.I.F., Pow I., Bridgen A. \& Reid H.W. 1993. PCR detection of sheepassociated agent of malignant catarrhal fever. Arch. Virol. 132:145-159.

Bridgen A. \& Reid H.W. 1991. Derivation of a DNA clone corresponding to the viral agent of sheep-associated malignant catarrhal fever. Res. Vet. Sci. 50:38-44.

Chmielewicz B., Goltz M. \& Ehlers B. 2001. Detection and multigenic characterization of a novel gammaherpesvirus in goats. Virus Res.75:8794.

Collery P. \& Foley A. 1996. An outbreak of malignant catarrhal fever in cattle in the Republic of Ireland. Vet. Rec. 139:16-17.

Collins J.K., Bruns C., Vermedahl T.L., Schiebel A.L., Jessen M.T., Schultheiss P.C., Anderson G.M., Dinsmore R.P., Callan R.J. \& DeMartini J.C. 2000. Malignant catarrhal fever: Polimerase chain reaction survey for ovine herpesvirus 2 and other persistent herpesvirus and retrovirus infections of dairy cattle and bison. J. Vet. Diagn. Invest. 12:406-411.

Coulter L.J., Wright H. \& Reid H.W. 2001. Molecular genomic characterization of the viruses of malignant catarrhal fever. J. Comp. Pathol. 124:2-19.

Crawford T.B., Li H. \& O'Toole D. 1999. Diagnosis of malignant catarrhal fever by PCR using formalin-fixed, paraffin-embedded tissues. J. Vet. Diagn. Invest. 11:111-116.

Crawford T.B., Li H., Rosenburg S.R., Norhausen R.W. \& Garner M.M. 2002.
Mural foliculitis and alopecia caused by infection with goat-associated malignant catarrhal fever virus in two sika deer. J. Am. Vet. Med. Assoc. 221:843-847.

Dabak M. \& Bulut H. 2003. Outbreak of malignant catarrhal fever in cattle in Turkey. Vet. Rec. 152:240-241.

Döbereiner J. \& Tokarnia C.H. 1959. Ocorrência da coriza gangrenosa dos bovinos no município de Serra Negra do Norte, Rio Grande do Norte. Arqs Inst. Biol. Animal, Rio de J., 2:65-82.

Driemeier D., Brito M.F., Traverso S.D., Cattani C. \& Cruz C.E.F. 2002. Outbreak of malignant catarrhal fever in brown brocket deer (Mazama gouazoubira) in Brazil. Vet. Rec. 151:271-272.

Figueiredo L.J.C., Castelo Branco M.B. \& Oliveira A.C. 1990. Aspectos clínicos e epidemiológicos da FCM. Anais $16^{\circ}$ Congr. Mundial Buiatria, Salvador, p.666-671.

Hamilton A.F. 1990. Account of three oubreaks of malgnant catarrhal fever in cattle in the Republic of Ireland. Vet. Rec. 127:231.

Heuschele W.P., Nielsen N.O., Oosterhuis J.E. \& Castro A.E. 1985. Dexamethasone-induced recrudescence of malignant catarrhal fever and associated lymphosarcoma and granulomatous disease in a Formosan sika deer (Cervus nippon taiouanus). Am. J. Vet. Res. 46:1578-1583.

Keel M.K., Patterson J.G., Noon T.H., Bradley G.A. \& Collins J.K. 2003. Caprine herpesvirus-2 in association with naturally occurring malignant catarrhal fever in captive sika deer (Cervus nippon). J. Vet. Diagn. Invest. 15:179-183.

Li H., Dyer N., Keller J. \& Crawford T.B. 2000. Newly recognized herpesvirus causing malignant catarrhal fever in white-tailed deer (Odocoileus virginianus). J. Clin. Microbiol. 1313-1318.

Li H., Keller J., Knowles D.P. \& Crawford T.B. 2001a. Recognition of another member of the malignant catarrhal fever virus group: an endemic gammaherpesvirus in domestic goats. J. Gen. Virol. 82:227-32.

Li H., Hua Y., Snowder G. \& Crawford T.B. 2001b. Levels of ovine herpesvirus 2 DNA in nasal secretion and blood of sheep: Implications for transmission. Vet. Microbiol. 79:301-310.

Li H., Gailbreath K., Bender L.C., West K., Keller J. \& Crawford T.B. $2003 a$. Evidence of three new members of malignant catarrhal fever virus group in muskox (Ovibos moschautus), Nubian ibex (Capra nubiana) and gemsbock (Oryx gazella). J. WId. Dis. 39:875-880.

Li H., Wunschman A., Keller J., Hall D.G. \& Crawford T.B. 2003b. Caprine herpesvírus-2-associated malignant catarrhal fever in white-tailed deer (Odocoileus virginianus). J. Vet. Diagn. Invest. 15:46-49.

Liggitt H.D. \& DeMartini J.C. 1980a. The pathomorphology of malignant catarrhal fever. 1. Generalized lymphoid vasculitis. Vet. Pathol. 17:58-72.

Liggitt H.D. \& DeMartini J.C. 1980b. The pathomorphology of malignant catarrhal fever. 2. Multisystemic epithelial lesions. Vet. Pathol. 17:7383.

Liggitt H.D., DeMartini J.C., McChesney A.E., Pierson R.E. \& Storz J. 1978. Experimental transmission of malignant catarrhal fever in cattle: Gross and histopathologic changes. Am. J. Vet. Res. 39:1249-1257.

Løken T., Aleksandersen M., Reid H. \& Pow I. 1998. Malignant catarrhal fever caused by ovine herpesvirus-2 in pigs in Norway. Vet. Rec. 143:464467.

Maniatis T., Fritsch E. F. \& Sambrook J. 1982. Molecular Cloning: A Laboratory Manual. Cold Spring Harbor, New York. 545p.

Marques L.C, Alessi A.C., Bechara G.H., Tomaz B.V., Marques J.A \& Guerra L. 1986. Surto de febre catarral maligna em bovinos no estado de São Paulo. Arq. Bras. Med. Vet. Zootec. 38:719-729.

Müller-Doblies U.U., Li H., Hauser B., Adler H. \& Ackermann M. 1998. Field validation of laboratory tests for clinical diagnosis of sheep-associated malignant catarrhal fever. J. Clin. Microbiol. 36:2970-2972.

O'Toole D., LI H., Roberts S., Rovnak J., DeMartini J.C., Cavender J., Williams B. \& Crawford T.B. 1995. Chronic generalized obliterative arteriopathy in cattle: a sequel to sheep-associated malignant catarrhal fever. J. Vet. Diagn. Invest. 7:108-121. 
O'Toole D., LI H., Miller D., Williams B. \& Crawford T.B. 1997. Chronic and recovered cases of sheep-associated malignant catarrhal fever in cattle. Vet Rec. 140:519-524.

Oliveira A.C., Figueiredo L.J.C. \& Resende A.M. 1978. Casos de febre catarral maligna ocorridos em Riachão de Jacuípe, Bahia. Descrição clínica e anátomo-patológica. 16을. Congr. Bras. Med. Vet., Salvador, p.130. (Resumo)

Otter A., Pow I. \& Reid H.W. 2002. Outbreak of malignant catarrhal fever in Welsh black cattle in Carmarthenshire. Vet. Rec. 151:321-324.

Pierson R.E., Thake D., McChesney A.E. \& Stortz J. 1973. An epizootic of malignant catarrhal fever in feedlot cattle J. Am. Vet. Med. Assoc. 163:349-350, 1973.

Pierson R.E., Storz J., McChesney A.E. \& Thake D. 1974. Experimental transmission of malignant catarrhal fever. Am. J. Vet. Res. 35:523-525.

Pierson R.E., Ramdy R.M., Dardiri A.H., Ferris D.H \& Schloer G.M. 1979. Comparison of American and African forms of malignant catarrhal fever: Transmission and clinical signs. Am. J. Vet. Res. 40:1091-1095.

Plowright W. 1968. Malignant catarrhal fever. J. Am. Vet. Med. Assoc. 152:795-806.

Plowright W. 1990. Malignant catarrhal fever virus, p.123-150. In: Morein B. \& Dinter Z. (ed.) Virus Infections of Ruminants. Elsevier Science Publishers, Amsterdam, The Netherlands. 592p.

Plowright W., Kalunda M., Jesset D.M. \& Herniman K.A.J. 1972. Congenital infection of cattle with the herpesvirus causing malignant catarrhal fever. Res. Vet. Sci.13: 253-266.

Raiser A.G., Mazzanti A., Lopes S.T.A., Brondani J.T., Souza C., Batina P., Salbego F.Z., Stieven D. \& Rohde R. 2003. Material alternativo de coleta de sangue em bovinos para transfusão. Hora Vet., Porto Alegre, 23: 39-42.

Reid H.W., Pow I. \& Buxton D. 1989. Antibody to alcelaphine herpesvírus-1 (AHV-1) in hamsters experimentally infected with AHV-1 and the "sheepassociated" agent of malignant catarrhal fever. Res. Vet. Sci. 47:383-386.

Riet-Correa F., Méndez M.C., Schild A.L., Brod C.S. \& Bondan E.F. 1988. Doenças diagnosticadas no ano de 1987. Laboratório Regional de Diagnóstico, p.15-16. Editora Gráfica Universitária, UFPel, Pelotas.

Roizman B., Carmichael L.E., Deinhardt F., De-The G., Nahmias A.J., Plowright W., Rapp F., Shelldrik P., Takahashi M. \& Wolf K. 1981.
Herpesviridae: Definition, provisional nomenclature and taxonomy. Intervirology 16:201-217.

Rossiter P.B., Jesset D.M., Mushi E.Z. \& Karstad L. 1983. Antibodies in carrier wildbeest to the lymphoproliferative herpesvirus of malignant catarrhal fever. Comp. Immunol. Microbiol. Infect. Dis. 6:39-43.

Rweyemamu M.M., Mushi E.Z., Rowe L. \& Karstadt L. 1976. Persistent infection of cattle with the herpesvirus of malignant catarrhal fever and observations on the pathogenesis of the disease. Brit. Vet. J. 132:393400.

Sampaio F.A., Sampaio A.A. \& Dacorso Filho P. 1972. Surto de febre catarral maligna em Campos, RJ. 8o Congr. Bras. Med. Veterinária, Brasília, p. 275. (Resumo)

Schultheiss P.C., Collins J.K., Austgen L.E. \& DeMartini J.C. 1998. Malignant catarrhal fever in bison, acute and chronic cases. J. Vet. Diagn. Invest. $10: 255-262$.

Selman I.E., Wiseman A., Murray M. \& Wright N.G. 1974. A clinicopathological study of bovine malignant catarrhal fever in Great Britain. Vet. Rec. 94:483-490.

Silva S.M.M.S., Cavalcante H.S., Viana G.E.N., Barbosa A.A. \& Silva S.A.V. 2001. Surto de febre catarral maligna. 9o Enapave, Pirassununga, p. 70. (Resumo)

Simon S., Li H., O'Toole D., Crawford T.B. \& Oaks J.L. 2003. The vascular lesions of a cow and bison with sheep-associated malignant catarrhal fever contain ovine herpesvirus 2-infected CD8 ${ }^{+}$T lymphocytes. J. Gen. Virol. 84:2009-2013.

Smith B.P. 2002. Malignant catarrhal fever, p 714-716. In: Ibid. (ed.) Large Animal Internal Medicine. Mosby, St. Louis. 1735p.

Stöber M. 1990. Identificação, anamnese, regras básicas da técnica de exame clínico geral, p. 44-80. In: Dirksen G., Gründner H.-D. \& Stöber M. (ed.) Rosemberger Exame Clínico dos Bovinos. 3르 ed. GuanabaraKoogan, Rio de Janeiro.

Tham K.M. 1997. Molecular and clinicopathological diagnosis of malignant catarrhal fever in cattle, deer and buffalo in New Zealand. Vet. Rec. 141:303-306.

Torres S. 1924. Óca, mal do chifre ou coryza gangrenosa dos bovinos. Bolm Soc. Bras. Med. Vet. 1:144-159. 